\title{
Towards a Life Cycle Sustainability Analysis: A Systematic Review of Approaches to Sustainable Manufacturing
}

\author{
Mijoh A. Gbededo ${ }^{a}$, Kapila Liyanage ${ }^{a}$ and Jose Arturo Garza-Reyes ${ }^{b}$ \\ ${ }^{a}$ College of Engineering and Technology, University of Derby, Markeaton Street DE22 3AW, UK \\ ${ }^{b}$ Centre for Supply Chain Improvement, University of Derby, Kedleston Road Campus, Derby, DE22 1GB, UK
}

\begin{abstract}
In 2011, the international organisations launched the Life Cycle Sustainability Assessment Framework for experts from different disciplinary fields to discuss and develop a holistic and integrated approach that supports effective sustainable development and sustainability decision-making. In response, various authors have used combinations of sustainable manufacturing methodologies and approaches to support this goal. This paper used a structured approach to a literature review to systematically examine sustainable manufacturing approaches between 2006 and 2015, and the move from segmented assessment methods to the holistic and integrated Life Cycle Sustainability Analysis. The analysis of the identified 54 relevant contributions indicated $68.5 \%$ of the articles focused on sustainable product development techniques, whereas $31.5 \%$ on sustainability assessment techniques. From the second, $70.4 \%$ of these were segmented approaches while only $29.6 \%$ incorporated the three sustainability dimensions. Further, the analysis showed that the energy aspect was incorporated into all the approaches, and there is a dearth of holistic approaches to sustainable manufacturing. Additionally, the paper initiates a theoretical framework that will underpin the development of a holistic simulation-based analytical framework that integrates goals that support progressive sustainable product development with methods that focus on the holistic quantitative analysis of the three sustainability dimensions.
\end{abstract}

Keywords: Life Cycle Sustainability Analysis, Sustainable Manufacturing, Sustainable Product Development, Sustainability Performance Assessment

\section{Introduction}

The challenges involved in extracting and transforming raw materials into consumers' product are enormous, and the unintended consequences of the associated activities are currently placing a great demand and additional responsibilities on how decisions are made in the manufacturing industries. Research has established that manufacturing activities are causing alarming degradation to the planet's natural resources and generating harmful effects on the general society (Cannata et al., 2009; Rahimifard et al. 2010; Aramcharoena and Mativenga, 2014; Ribeiro and Kruglianskas, 2013; Kalakul et al.,2014). In the past, before the declaration of Brundtland report tagged "Our Common Future", the objectives of the 
manufacturing industries were based on increasing economic efficiency and strengthening their material wealth (Stevens, 2005; Almeida et al., 2015). The advent of Brundtland report places demands on industries to evaluate their performances toward "meeting the needs of the present generation without compromising the ability of future generations to meet their own needs" (Brundtland, 1987, p. 16). The report has been interpreted to anchor on three sustainability dimensions: economic development, social development and environmental protection (Mastoris, 2011; Luong et al., 2012; Zamagni et al., 2013). Since the adoption of this declaration by international bodies, regulatory and legislative pressures on manufacturing industries have increased, and there have been prevailing changes in consumers' demand pattern towards more sustainable products and practices (Melville and Ross, 2010; Rahimifard et al. 2010; Cataldo et al., 2013; Bonnie et al., 2014). Thus, the current global focus is now on supporting and coercing manufacturing industries to implement cleaner and more efficient production practices that enable development of products and services with reduced negative environmental and societal impacts (Stevens, 2005; OECD 2010; Zeng et al., 2010; Ribeiro and Kruglianskas, 2013; Kubota and Da Rosa, 2013).

The US Department of Commerce defines sustainable manufacturing as "the creation of manufactured products that use processes that minimise negative environmental impacts, conserve energy and natural resources, are safe for employees, communities, and consumers and are economically sound". Thus, the need for manufacturing industries, in addition to economic efficiency, is to assess the environmental and social objectives in advancing manufacturing operations, technologies, and competitive position (Rosen and Kishawy, 2012). However, case studies and research have shown that the adoption of sustainable product development is a great challenge due to various factors including the lack of a standard holistic assessment framework to support effective decision-making and for its implementation (Paju, et al., 2010; Bhanot et al., 2015). The impacts of the challenge accounted for the current trend of non-holistic approaches to sustainable product development where optimisation of environmental related factors such as materials and energy efficiencies are being integrated with competitive manufacturing strategies (Kibira and McLean, 2006; Haapala et al., 2011; Casamayor and Su, 2013; Keskin et al., 2013; Aydin et al., 2015; Gelbmann and Hammerl, 2015). Another contemporary approach in practice is the ISO 14044 Life Cycle Assessment (LCA) framework, which is commonly used for environmental assessment of a product lifecycle. However, the LCA framework is environmental centric, segmented and does not support effective sustainability decisionmaking during product development (Krozer and Vis, 1998; Pryshlakivsky and Searcy, 2013). The use of Life Cycle Costing (LCC) and Social Life Cycle Assessment (S-LCA) have also emerged with the LCA framework to sequentially or inter-dependently analyse the impact of the three dimensions throughout a product lifecycle (Heijungs et al., 2009; UNEP/ SETAC, 2009; Mitchell and Radu, 2011; Hong et al. 2012). Thus, the current research approaches can be categorised into four streams: 1) Segmented sustainable product development; 2) Integrated sustainable product development; 3) Segmented sustainability performance assessment; and 4) Integrated sustainability performance assessment. 
In 2011, the United Nations Environment Programme (UNEP) and Society of Environmental Toxicology and Chemistry (SETAC) (UNEP/SETAC, 2011), under its Life Cycle Initiative programme, published a framework to support the development of a holistic Life Cycle Sustainability Assessment (LCSA). The framework provides the stage for a new approach to sustainability subject among scientists, researchers, and practitioners to discuss and implement sustainable development with a holistic life cycle perspective (UNEP/SETAC, 2011; Parent et al., 2013; Valdivia et al., 2013; Zamagni et al., 2013)

However, despite the aforementioned argument, discussion shows some moderated degree of research and institutional/industrial activity in the field of sustainable manufacturing and scholarly research on sustainability assessment techniques. Thus, research on the application of Life Cycle Sustainability Analysis still remains limited and in early stages. In addition, this contemporary research stream still lacks of a structured and clear research definition, which may hinder the advancement of this important field. Therefore, in order to facilitate and further the progress of research in this field, this paper examines, within the manufacturing sector, different approaches towards sustainable manufacturing, and determines the direction and trend from partial or segmented assessment methods to an integrated holistic assessment of the sustainability dimensions. In addition, the study also aims at identifying gaps both in practice and research within the context of the manufacturing sector. Similarly, the paper proposes a framework that integrates goals that support a progressive sustainable product development with methods that focus on the holistic quantitative analysis of manufacturing processes. To do this, the paper systematically identifies and critically analyses existing contributions in the field of sustainable manufacturing, with a particular interest in sustainability assessment techniques and Life Cycle Sustainability Analysis.

In the subsequent section, we discussed the research methodology used in the conducted literature review, followed by the results and discussions of the findings in section 3. The theoretical development process for the proposed integrated framework is detailed in Section 4, and Section 5 provides the summary, identified research gaps and directions, and the conclusions.

\section{Methodology}

The research methodology adopted to conduct a literature review is critical to the validity of the results, applicability, and outcomes of the review (Goodall et al., 2014; Garza-Reyes, 2015). This research adopts a structured approach to perform a full literature review; a method that is systematic, transparent, methodical and reproducible to inform policy and decision-making (Tranfiel et al., 2003; Goodall et al., 2014). Tranfield et al. (2003) espoused three phases of processes which have been adopted by various researchers to systematically review full literature based on a defined research question, goals and scope (e.g. Chang et al., 2014; Garza-Reyes, 2015; Brones et al., 2015; Esmaeilian et al., 2016; Fakhimi et al., 2016). The three steps process involves data collection, data analysis, and synthesis. Goodall et al. (2014) define the three stages as the scope of the study, search strategy, and evaluation of the material method. Esmaeilian et al. (2016) expounded on these in a three-stage qualitative research method as identification, classification, and evaluation. 
The identification stage, which is the data collection phase, consists in identifying studies through a search of scholarly databases (such as electronics database, and the web of science), limited by the defined goals and scope of the review such as articles date, type, and keywords (Garza-Reyes, 2015). The classification stage, similarly to the data analysis phase, is the process of organising articles according to approaches and techniques, and in a way that they can easily be accessed and retrieved. Finally, the evaluation stage involves the analysis and synthesis of the quantitative and qualitative results into an interpretive pattern or summary (Brones et al., 2015). Thus, in reference to the above reviewed methods, this study adopts a four-phase approach as depicted in Figure 1. The phases include: 1) The definition of the research problem, 2) The data collection, 3) The data analysis and synthesis, and 5) The result reporting and discussions phases.

\begin{tabular}{|c|c|c|c|c|}
\hline & $\begin{array}{c}\text { Phase 1 } \\
\text { (Section 2.1) }\end{array}$ & $\begin{array}{c}\text { Phase 2 } \\
\text { (Section 2.2) }\end{array}$ & $\begin{array}{c}\text { Phase 3 } \\
\text { (Section 2.3) }\end{array}$ & $\begin{array}{c}\text { Phase } 4 \\
\text { (Section 3) }\end{array}$ \\
\hline Objectives & $\begin{array}{c}\text { Problem } \\
\text { Definition }\end{array}$ & $\overbrace{\text { Data meets }}^{\text {No }}$ & $\begin{array}{l}\text { Data Analysis } \\
\text { and Synthesis }\end{array}$ & $\begin{array}{l}\text { Result and } \\
\text { discussion }\end{array}$ \\
\hline $\begin{array}{l}\text { Focuses/ } \\
\text { strategies }\end{array}$ & $\begin{array}{l}\text { * Formulation of } \\
\text { research question } \\
* \text { Definition of } \\
\text { goal and scope }\end{array}$ & $\begin{array}{l}\text { * Identification of studies, data types, and sources } \\
\text {-Inclusion criteria: discrete manufacturing, production } \\
\text { process level assessments, } 2006<=\text { year }>=2015 \\
\text {-Exclusion criteria: system level (supply chain) and } \\
\text { product level (product lifecycle) assessments, } \\
\text { continuous manufacturing }\end{array}$ & $\begin{array}{l}\text { * Determination of data-of- } \\
\text { interest: } \\
\text {-SPD vs SPA approaches } \\
\text {-Integrated vs segmented } \\
\text {-Publications' trends } \\
\text { * Gaps in the research }\end{array}$ & $\begin{array}{l}* \text { Interpretations } \\
\text { and discussions } \\
\text { of results }\end{array}$ \\
\hline $\begin{array}{l}\text { Tools \& } \\
\text { Techniques }\end{array}$ & & $\begin{array}{l}\text { * Access to peer-reviewed articles } \\
\text { - Bibliographic databases } \\
\text { * Search, sort \& eliminate; * Abstract \& Introduction } \\
\text { * Strings of keywords for search: } \\
\text { - Sustainability assessment of manufacturing, LCSA, } \\
\text { Sustainable manufacturing, Green house Gas, Energy } \\
\text { modelling, CSR, eco-innovation... }\end{array}$ & $\begin{array}{l}\text { * Organisation of articles } \\
\text { * Classification of data } \\
\text {-Mendeley reference } \\
\text { manager } \\
\text {-Exploratory data analysis } \\
\text { (EDA) techniques } \\
\text {-Thematic approach }\end{array}$ & $\begin{array}{l}\text { * Quantitative } \\
\text {-Tabular and } \\
\text { thematic } \\
\text { presentation } \\
\text { * Graphical } \\
\text {-histograms } \\
\text {-scatter plots }\end{array}$ \\
\hline
\end{tabular}

Figure 1. Phases, objectives, focuses and tools for a systematic literature review

\subsection{Problem Definition Phase}

The Correct identification of a research problem is critical to finding the right path and solution to a phenomenon. This is often clearly stated in a problem statement or refined in a research question and includes the description of the goals and scope of the investigation (Gall et al., 2006). In respect of the research question, this review focused on identifying the approaches to sustainable manufacturing and determining up to what extent these approaches have transitioned from segmented assessment methods to the holistic and integrated LCSA. The goal was to identify gaps both in practice and research within the boundary of the gateto-gate manufacturing production domain. The scope was limited to the manufacturing production domain and the literature published between 2006 and 2015 (inclusive) on approaches to sustainable manufacturing. The purpose was to focus on the product and 
process design phase of manufacturing which is central to sustainability decision-making and most previous and up to date methodologies after UNEP/SETAC launched the LCSA framework in 2011 (UNEP/SETAC, 2011). It is worth noting that LCA standard was first adopted by the International Standard Organisation (ISO) from the code of practice developed by SETAC in 1990 and the collaboration of SETAC and UNEP further enabled its worldwide acceptance in 2002 (Klöpffer, 2006; Pryshlakivsky and Searcy, 2013). The delimited manufacturing production domain was established to allow focus on methodologies adopted for assessment of a discrete manufacturing production process for a product under design.

\subsection{Data Collection Phase}

Due to the current global significance of the sustainability subject, there are proliferations of articles and literature on the topic cutting across the boundaries of every field of studies. Hence, the use of a keyword such as "sustainability" or "sustainable" in a search engine will generate an overwhelming volume of data. The main focus of data collection phase is identifying the data types, sources, and defining the inclusion and exclusion criteria relevant to the problem statement of the review (Garza-Reyes, 2015). In this study, a search for peerreviewed articles on approaches to sustainable manufacturing were conducted using strings of keywords (this is to ensure relevant articles are collected) to search major online bibliographic databases such as World of Science (WoS), the University Library Catalogue, Science Direct, and Google Scholar (Garza-Reyes, 2015). The use of Mendeley software enabled the processing and management of overlapped articles collected from the various sources. A further manual checking through the reading of the "abstracts" and "introductions" enabled elimination of irrelevant articles from the collections. The search included articles that used quantitative assessment approach and those that used the qualitative approach to new product development and continuous product improvement. Sustainable manufacturing development can be categorised into three types of assessment levels: 1) System level assessment which includes the assessment of an entire supply chain of a product development process, 2) Product level assessment which include the assessment of a whole product life cycle from cradle to grave or end of life choice, and 3) Process level assessment which involves the assessment of a processing stage in a product lifecycle such as the manufacturing production process (Jayal et al., 2010; Parent et al., 2012). The system level and the product level assessments were excluded in the data collection as they fell outside the boundaries of the defined scope of this study. The process level assessment is defined by the gate-to-gate boundaries (Gbededo et al., 2016) of a product lifecycle stage. The continuous production process was also excluded in order to focus on the discrete manufacturing process. The ten years range for collection allows for a balance of five years prior to the launch of the LCSA framework and five years from when it was launched. This enabled the inclusion or articles published in 2011 to be included as post launched. In addition to the scope defined in the problem statements, the delimited articles enhanced the speed of data collection and ensure analysis of a complete representation of a stage of a manufacturing type.

\subsection{Data Analysis and Synthesis Phase}


This phase is characterised by determining the data of interest, that is; what the researcher is looking for in the collected data, this underpins the data coding and choice of analytical tool appropriate for the analysis. Based on the problem statement, the approaches to sustainable manufacturing adopted by the reviewed authors, and the year of publication are of key importance to this study. In addition, the identification of the methods that are segmented and the combination groups of the sustainability dimensions in the segments are also important to our analysis. Those articles which included the three dimensions; some authors summed up the three parts while others suggested aggregation in an analytical equation. According to Brones et al. (2015) synthesis is the most valuable process that involves the generation of new knowledge, based on complete data collection and meticulous analysis. There are various techniques for the data synthesis of quantitative and qualitative literature reviews that include thematic approach, bibliometrics, meta-analysis, and content analysis (Garza-Reyes, 2015; Brones et al., 2015). Thematic synthesis, as used by Garza-Reyes, (2015), was adopted in this case due to its effectiveness in summarising, synthesising and classifying qualitative research into structured themes as depicted in Figure 2 [A]. With exploratory data analysis (EDA), the trend and relationships between the two major sustainable manufacturing approaches before and after the launch of the LCSA was established as shown in Figure 3. EDA is a robust data analysis technique which provides insight into the underlying structure of a data (Behrens and Yu, 2003).

\section{Results and Discussion}

The data collection process produced a total of 54 articles relevant to the approach to sustainable manufacturing within the defined goal and scope. The data analysis categorised the literature into the two techniques adopted for sustainable manufacturing, i.e. Sustainable Product Development (SPD) techniques - 36 (66.7\%) articles and Sustainability Performance Assessment (SPA) techniques - 18 (33.3\%) articles, see Figure 2 [A]. From these, 38 (70.4\%) of the papers focused on the segmented approach to sustainable manufacturing while 16 (29.6\%) incorporated the three sustainability dimensions in their approach. Of the 38 segmented approaches, 35 (92.1\%) included environmental, 14 (36.8\%) included economic and 8 (21.1\%) included social aspects with at least one of the other sustainability dimensions in their assessments. These are denoted by plus environmental, plus economic, and plus social dimensions respectively in Figure 2 [B]. The result indicates a higher focus (92.1\%) on environmental issues as compared to other sustainability challenges. The segmented approaches were deemed partial approaches to sustainable manufacturing due to the lack of a holistic approach that simultaneously considered the three sustainability dimensions. Furthermore, the analysis showed that all of the 35 (100\%) papers of the segmented approaches that included environmental dimension concentrated on the energy aspect and only $5(14.3 \%)$ included materials and other aspects that related to the environmental dimension; see Figure 2 [C]. The result revealed the imbalance of the approaches towards the three sustainability dimensions, with a greater neglect on the importance of the social dimension and its interconnection with the other dimensions. It also showed the fact that the current sustainable manufacturing approaches tend to focus more on competitive manufacturing that integrates environmental protection elements such as energy 
consumption. There are also limited papers in Sustainability Performance Assessment techniques (33.3\%), when compared to those techniques that foster the continuous improvement and development of sustainable products (66.7\%). The insufficient research in the holistic quantitative sustainability assessment techniques such as LCSA, explains the high volume of literature present in the segmented approach to sustainable manufacturing.
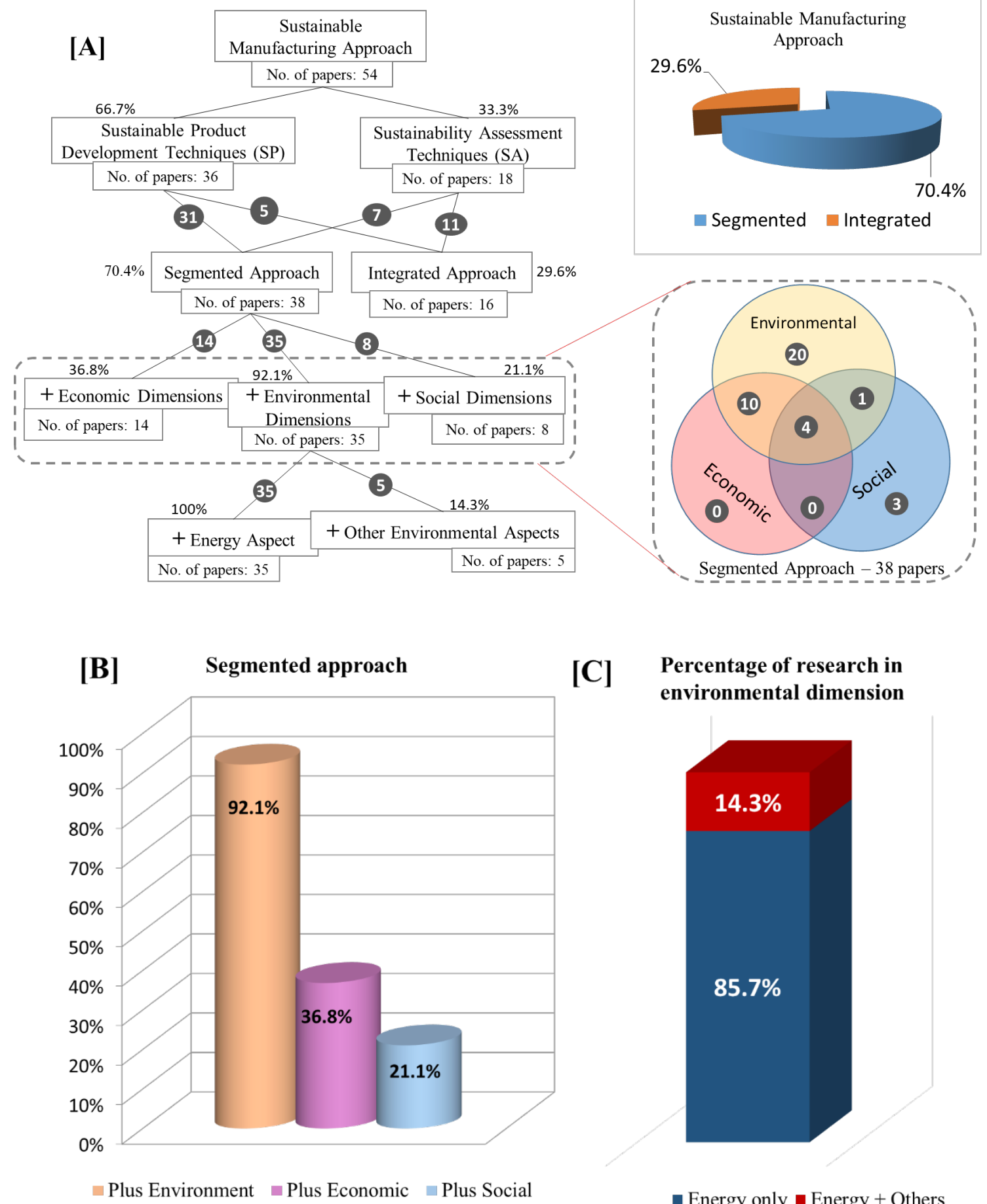

[C] Percentage of research in environmental dimension

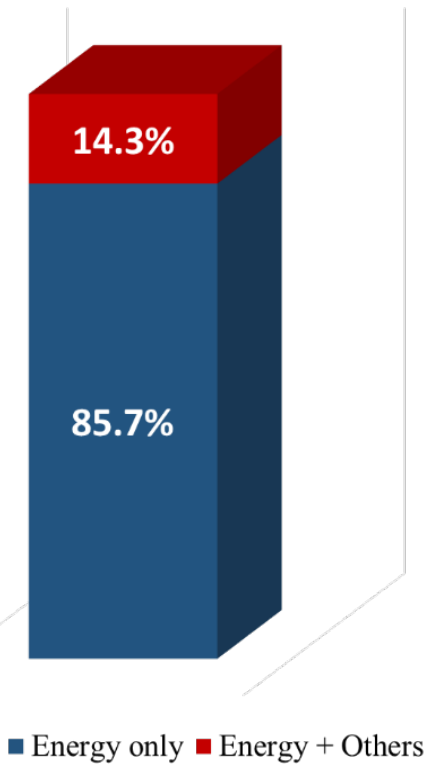

Figure 2. Classification of the focus of sustainable manufacturing approaches 
The data analysis further examined the trend of the approaches to integrated sustainable manufacturing from 2006 to 2015. It was observed that the number of articles in this area increased after the launch of LCSA in 2011 (UNEP/SETAC, 2011), however, there was a fall after the peak in 2013, Figure 3. This explains the initial enthusiasm towards the implementation of the holistic approach at the launch of the LCSA framework and the existing fundamental difficulties in integrating the social aspects concurrently with economic and environmental dimensions as indicated in related articles.

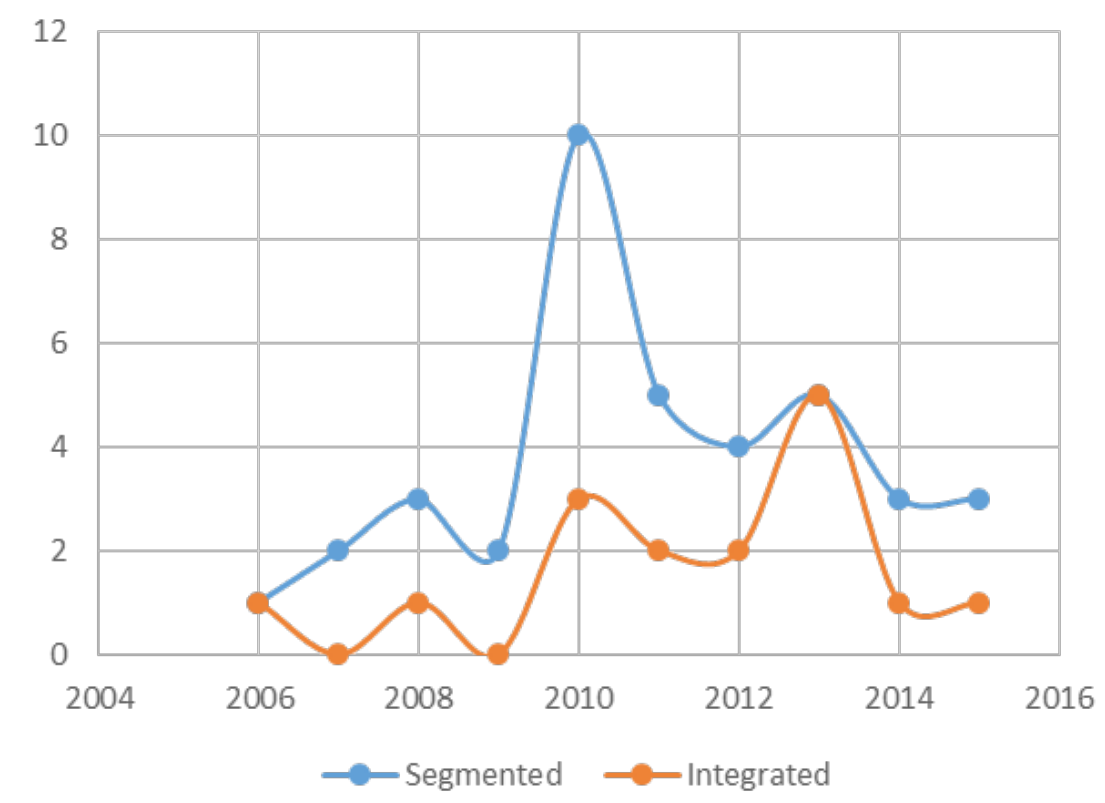

Figure 3. Trend of approach to sustainable manufacturing between 2006 and 2015

\section{1. $\quad$ Segmented Sustainability Performance Assessment}

The manufacturing industry remains the focal point for measuring economic, social and environmental sustainability; this is due, in part, to the volume of natural resources consumed and the amount of wastes and environmental pollution generated by this sector (Brundtland, 1987; Kibira and McLean, 2006; Esmaeilian et al., 2016). The effective assessments of the three sustainability dimensions underpin the development of un-abridged sustainable products; these are discussed in many of the articles with different views and approaches, ranging from segmented to simultaneous assessments. As shown in Figure 2, most of the approaches are segmented, with overlaps in their classifications due to the existence of a sustainability factor in one or more than one combination of the partial assessment. However, approaches that devoid the simultaneous consideration of the three sustainability dimensions lack a holistic view and can neither produce a sustainable product nor support effective sustainability decision-making. Authors such as Hermann et al. (2007); Portha et al. (2010); Luz et al. (2010) and Arena et al. (2013) concentrate only on the assessment of the environmental performance while Page and Wohlgemuth (2010) and Chang et al. (2014) 
incorporate the assessments of the environmental and economic performance in their strategies, and Benoît et al. (2010) concentrate on the guidelines for social performance assessment. In Hermann et al. (2007) approach, the authors combined environmental performance indicators, lifecycle approach and multi-criteria analysis to assess the overall environmental impact of a business. Portha et al. (2010) applied LCA to assess the sustainability of catalytic reforming process using Eco-Indicator99 as a life cycle impact assessment method to identify environmental impacts on different process parameters. Luz et al. (2010) applied a comparative LCA approach to material substitution by comparing two alternatives for polypropylene composites materials. Arena et al. (2013) applied a streamlined LCA to consider each lifecycle stages of a car lifecycle in a more analytical way rather than viewing it as a set of or summary of indicators. Page and Wohlgemuth (2010) applied discrete event simulation to model eco-efficient systems such as complex production systems with a focus on process impacts on economic and environmental dimensions.

The International Standard Organisation (ISO) has also developed a series of international standards (ISO14000 series) that demand continuous improvement in industries' Environmental Management System (EMS) (http://www.iso.org/iso/iso14000). The framework is a segmented approach used by many product designers for assessing the environmental impacts of a product from cradle to grave (Krozer and Vis, 1998; Consultants, 2000; Pryshlakivsky and Searcy, 2013). It consists of four phases: Goals and Scope Definition, Inventory Analysis, Impact Assessment, and Interpretation (http://www.iso.org/iso/iso14000). "ISO14040: 2006 \& 2010 for example; defines the principles and framework for Life Cycle Assessment (LCA); ISO14001: 1996 \& 2015 supports Environmental Auditing; ISO14031:2013 provides guidelines for Environmental Performance Evaluation (EPE); ISO14020:2000 states the guidelines for environmental labels and declarations. The ISO14004:2004 defines the EMS general guidelines on principles, systems, and support techniques. ISO14001:1996 is for EMS and the only ISO14000 standard against which it is possible to be certified by an external certification body”. There are other methodologies such as Life Cycle Costing (LCC) and Social Life Cycle Assessment (S-LCA) that are based on LCA principles (UNEP/SETAC, 2009; Mitchell and Radu, 2011). Economic Input-Output (EIO) LCA models such as Physical Input Monetary Output (PIMO) and Materials Flow Analysis (MFA) models support the assessment of environmental impact of materials flow within an ecological-economic system (Halog and Manik, 2011).

\subsection{Segmented Sustainable Product Development - The Innovative-Approach}

The enormous impacts of manufacturing activities on the environment and the need for resource conservation have attracted a high volume of research focus seen on eco-innovative and eco-design approaches to sustainable product development. Over $90 \%$ of the reviewed segmented approaches are environmentally related and energy aspects being embedded in all of these. Authors such as Ijomah et al. (2007); Ostlin et al. (2009) and Hatcher et al. (2014) have concentrated on approaches that reduce impacts on the environment through design for remanufacturing; Duflou et al. (2008) focused on feasibility of design for disassembly; Abramovici and Lindner (2011) product life cycle knowledge discovery methods supported 
by an information technology systems; and Bakker et al. (2014) the implications of product lifespan extension. Other authors have balanced the environmental aspects with a sound economic approach. For instance, Yang et al. (2011) incorporated economic and environmental aspects such as lean-green and competitive sustainable manufacturing; Jovane et al. (2008) discussed the use of a Reference Model for Proactive Action (RMfPA) to enable the development and implementation of Competitive Sustainable Manufacturing (CSM); Gremyr et al. (2014) presented the application of the Robust Design Methodology for quality management in Sustainable Product development. Other authors deployed a sequential approach to address the three sustainability dimensions. In this line, Aguado et al. (2013) used innovation, lean techniques, and sustainable manufacturing to harmonise efficiency and competitiveness; Afgan (2010) used Information Systems to monitor and evaluate energy efficiency; Kibira and McLean (2006) employed simulation metrics, software tools, interface standards, and data sets. There are, however, various terms such as eco-innovation, circular economy, design-for-environment, eco-design, design for remanufacturing, design for recycling, and eco-efficient used in a large number of the articles on segmented product development to define design techniques, methods and approaches that aim to reduce environmental impact of products development (e.g. Ostlin et al., 2009; OECD, 2010; Hatcher et al., 2014; Cluzel et al., 2014). According to Cluzel et al. (2014), some of these terms carry misconceptions and an unclear purpose within the practitioners. Thus, finding a clear understanding and relationships between these terms is of principal importance to the development and application of an effective approach to sustainable production.

\subsubsection{Sustainable Product Development versus Eco-innovation}

The Organisation for Economic Co-operation and Development (OECD) defined ecoinnovation as a "strategic business innovation that aims at improving competitiveness and reducing environmental impact”. OECD (2010) emphasised that the focus of eco-innovation is on change, redesign or modification of products, processes, and organisational systems such as technology, policy, and services in order to achieve both competitive and sustainable development. For instance, some authors emphasised eco-design such as product modularity and remanufacturing techniques in order to extend the life span of a product and conserve resource depletion (Ijomah et al., 2007; Duflou et al., 2008; Ostlin et al., 2009; Hatcher et al., 2014; Bakker et al., 2014), whereas others have focused on energy modelling and simulation techniques in order to improve the energy efficiency of the production process and the product (Cannata et al., 2009; Rajemi et al., 2010; Rahimifard et al. 2010; Melville and Ross, 2010; Afgan, 2010; Seow et al., 2013; Aramcharoena and Mativenga, 2014). Similarly, other authors have focus on lean-green and materials substitution techniques in order to improve product materials efficiency and business performance (Alves et al., 2010; Yang et al., 2011; Aguado et al., 2013; Crabbé, et al., 2013). Thus, according to the OECD (2010), eco-innovation has a three-dimensional approach to competitive sustainable manufacturing and can best be understood and analysed according to these dimensions. As stated by OECD (2010), the first dimension is TARGETS such as products, processes or technology to be changed, enhanced or renovated due to its negative impacts on the environment; then the MECHANISMS to be adopted to implement the change required in the 
"target”, e.g. modification, redesign, remanufacturing, creation or the use of alternative products, process, marketing methods or information systems. The third dimension is IMPACTS which identifies the effect that the changes will have on the environment, e.g. energy consumption, solid waste, and air emission. Thus, eco-innovation is a methodology of a complete system that combines different methods and approaches to manufacture a competitive environmental friendly product. Figure 4 depicts the relationship between ecoinnovation and other terms reviewed in this article. The emphasis on competitiveness and environmental friendliness distinct eco-innovation from other methods and terms discussed hereafter.

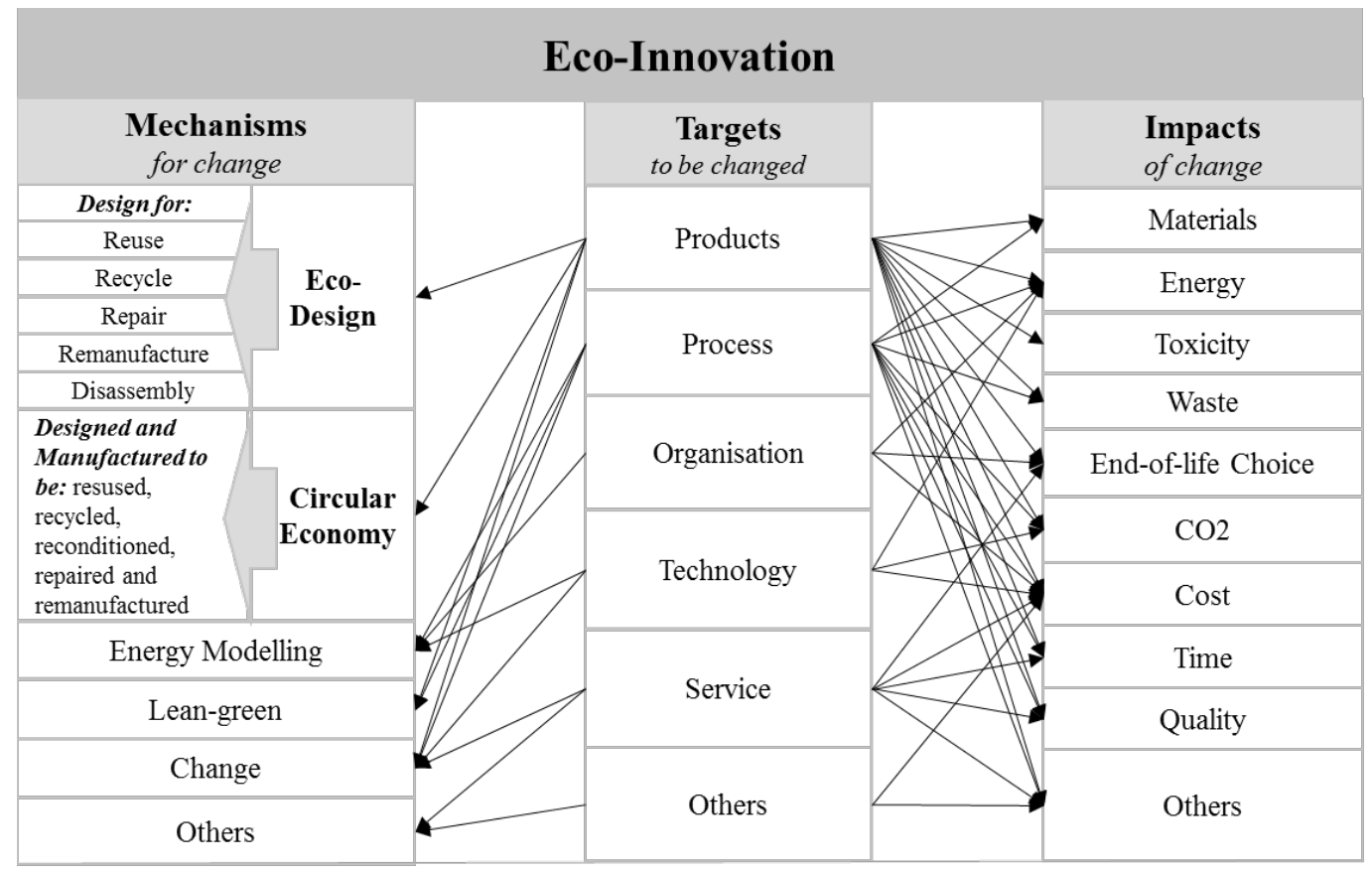

Figure 4. Design for eco-efficiency of production system: eco-innovation approach

Table 1 shows a summary of various segmented and eco-innovative approaches adopted by researchers for sustainable product development within the reviewed literature. The main challenge with these methods is the lack of consideration for the three sustainability dimensions and interdependent assessments of the impact of one dimension on the others. The assessments methods are either segmented or performed in a sequential order, which does not support effective decision-making for sustainable development.

Table 1 Summary of research based on segmented approaches to sustainable manufacturing

\begin{tabular}{|c|c|c|c|c|c|c|}
\hline \multirow[t]{2}{*}{ Targets } & \multirow{2}{*}{$\begin{array}{l}\text { Mechanism } \\
\text { For Change }\end{array}$} & \multirow[b]{2}{*}{ Description } & \multicolumn{3}{|c|}{ Impacts } & \multirow[t]{2}{*}{ Authors } \\
\hline & & & En & Eco & Soc & \\
\hline \multirow[b]{2}{*}{ Product } & & Design for remanufacture & $\sqrt{ }$ & - & - & $\begin{array}{l}\text { Ostlin et al. (2009) } \\
\text { Hatcher et al. } \\
\text { (2014) }\end{array}$ \\
\hline & Eco-Design & $\begin{array}{l}\text { Knowledge Discovery Methods } \\
\text { Supported by an IT Prototype Of A }\end{array}$ & $\sqrt{ }$ & - & - & $\begin{array}{l}\text { Abramovici and } \\
\text { Lindner (2011) }\end{array}$ \\
\hline
\end{tabular}




\begin{tabular}{|c|c|c|c|c|c|c|}
\hline & & Design Assistant System & & & & \\
\hline & & $\begin{array}{l}\text { Implications of product lifespan } \\
\text { extension }\end{array}$ & $\sqrt{ }$ & - & - & Bakker et al. (2014) \\
\hline & & Feasibility of design for disassembly & $\sqrt{ }$ & - & - & Duflou et al. (2008) \\
\hline & & $\begin{array}{l}\text { Guidelines to Facilitate } \\
\text { Remanufacturing }\end{array}$ & $\checkmark$ & - & - & Ijomah et al. (2007) \\
\hline & & $\begin{array}{l}\text { Environmental Impact and Economic } \\
\text { Cost }\end{array}$ & $\sqrt{ }$ & & & Lim et al. (2013) \\
\hline & Lean-green & $\begin{array}{l}\text { Effect of Lean \& Environmental } \\
\text { Manufacturing on Business } \\
\text { performance }\end{array}$ & $\sqrt{ }$ & $\sqrt{ }$ & - & Yang et al. (2011) \\
\hline $\begin{array}{l}\text { Product \& } \\
\text { Process }\end{array}$ & $\begin{array}{l}\text { Reference } \\
\text { Model for } \\
\text { Proactive } \\
\text { Action } \\
\text { (RMfPA) }\end{array}$ & $\begin{array}{l}\text { To enable development and } \\
\text { implementation of Competitive } \\
\text { Sustainable Manufacturing (CSM) }\end{array}$ & $\sqrt{ }$ & $\sqrt{ }$ & - & Jovane et al. (2008) \\
\hline & EMERGY & $\begin{array}{l}\text { Use of Emergy Accounting for } \\
\text { material and process selection }\end{array}$ & $\sqrt{ }$ & $\sqrt{ }$ & - & $\begin{array}{l}\text { Almeida et al. } \\
\text { (2010) }\end{array}$ \\
\hline & $\begin{array}{l}\text { Robust Design } \\
\text { Methodology } \\
\text { (RDM) }\end{array}$ & $\begin{array}{l}\text { Application of RDM quality } \\
\text { management in Sustainable Product } \\
\text { Development }\end{array}$ & $\sqrt{ }$ & $\sqrt{ }$ & - & $\begin{array}{l}\text { Gremyr et al. } \\
\text { (2014) }\end{array}$ \\
\hline & & $\begin{array}{l}\text { Use of Simulation \& Virtual Reality } \\
\text { for production management }\end{array}$ & $\sqrt{ }$ & $\sqrt{ }$ & - & Abidi et al. (2016) \\
\hline & & $\begin{array}{l}\text { Analysis of different Machine } \\
\text { parameters }\end{array}$ & $\sqrt{ }$ & - & - & $\begin{array}{l}\text { Bhanot et al. } \\
\text { (2015) }\end{array}$ \\
\hline & & $\begin{array}{l}\text { Modelling present and future state } \\
\text { VSM+LCA+DES }\end{array}$ & $\sqrt{ }$ & $\sqrt{ }$ & - & Paju, et al. (2010) \\
\hline & Simulation, & $\begin{array}{l}\text { Sustainability of Unconventional } \\
\text { Machining (UCM) }\end{array}$ & $\sqrt{ }$ & - & - & $\begin{array}{l}\text { Gamage and } \\
\text { DeSilva (2015) }\end{array}$ \\
\hline $\begin{array}{l}\text { Production } \\
\text { Process }\end{array}$ & $\begin{array}{l}\text { Energy } \\
\text { Modelling, }\end{array}$ & $\begin{array}{l}\text { Simulation metrics, software tools, } \\
\text { interface standards, and data sets. }\end{array}$ & $\sqrt{ }$ & $\sqrt{ }$ & $\sqrt{ }$ & $\begin{array}{l}\text { Kibira and McLean } \\
\text { (2006) }\end{array}$ \\
\hline $\begin{array}{l}\text { Energy } \\
\text { Efficiency }\end{array}$ & $\begin{array}{l}\text { Monitoring \& } \\
\text { Evaluation }\end{array}$ & $\begin{array}{l}\text { Simulation and Event-log analysis for } \\
\text { data collection }\end{array}$ & $\sqrt{ }$ & - & - & $\begin{array}{l}\text { Rai and Daniels } \\
\text { (2015) }\end{array}$ \\
\hline & & $\begin{array}{l}\text { Use of Information System to } \\
\text { monitor and evaluate energy } \\
\text { efficiency }\end{array}$ & $\sqrt{ }$ & $\sqrt{ }$ & $\sqrt{ }$ & Afgan (2010) \\
\hline & & $\begin{array}{l}\text { Energy prediction for materials and } \\
\text { process selection }\end{array}$ & $\sqrt{ }$ & - & - & $\begin{array}{l}\text { Aramcharoena and } \\
\text { Mativenga (2014) }\end{array}$ \\
\hline & & $\begin{array}{l}\text { Energy monitoring, analysis, and } \\
\text { management }\end{array}$ & $\sqrt{ }$ & - & - & $\begin{array}{l}\text { Cannata et al. } \\
\text { (2009) }\end{array}$ \\
\hline & & Simulation-based energy monitoring & $\sqrt{ }$ & - & - & Seow et al. (2013) \\
\hline & $\begin{array}{l}\text { Energy } \\
\text { Efficiency }\end{array}$ & $\begin{array}{l}\text { Simulation-based energy usage } \\
\text { analysis }\end{array}$ & $\sqrt{ }$ & - & - & $\begin{array}{l}\text { Solding et al. } \\
\text { (2009) }\end{array}$ \\
\hline & & $\begin{array}{l}\text { Simulation and modelling of } \\
\text { environmental aspects of } \\
\text { sustainability. }\end{array}$ & $\mathrm{V}$ & - & - & Thiede et al. (2013) \\
\hline & & $\begin{array}{l}\text { SIMIO DES to optimise and evaluate } \\
\text { energy consumption }\end{array}$ & $\sqrt{ }$ & - & - & $\begin{array}{l}\text { Cataldo et al. } \\
\text { (2013) }\end{array}$ \\
\hline & & $\begin{array}{l}\text { Energy-oriented simulation model } \\
\text { for production planning and } \\
\text { controlling }\end{array}$ & $\sqrt{ }$ & - & - & $\begin{array}{l}\text { Herrmann et al. } \\
\text { (2011) }\end{array}$ \\
\hline & & $\begin{array}{l}\text { Energy consumption prediction } \\
\text { during product design and process } \\
\text { planning stages. }\end{array}$ & $\sqrt{ }$ & - & - & Kara and Li (2011) \\
\hline & & Modifying cutting condition / by & $\sqrt{ }$ & - & - & Mori et al. (2011) \\
\hline
\end{tabular}




\begin{tabular}{|c|c|c|c|c|c|c|}
\hline & & $\begin{array}{l}\text { developing advanced machine } \\
\text { conditions }\end{array}$ & & & & \\
\hline & & $\begin{array}{l}\text { Detailed breakdown of energy } \\
\text { required for production (EPE) to } \\
\text { support energy efficiency }\end{array}$ & $\sqrt{ }$ & - & - & $\begin{array}{l}\text { Rahimifard et al. } \\
(2010)\end{array}$ \\
\hline & & $\begin{array}{l}\text { Optimisation of Energy footprint for } \\
\text { machine product }\end{array}$ & $\sqrt{ }$ & - & - & Rajemi et al. (2010) \\
\hline & & $\begin{array}{l}\text { Use of Information System for } \\
\text { gathering, evaluating and improving } \\
\text { environmental responsibility }\end{array}$ & $\sqrt{ }$ & - & - & $\begin{array}{l}\text { Melville and Ross } \\
\text { (2010) }\end{array}$ \\
\hline \multirow{3}{*}{$\begin{array}{l}\text { Product } \\
\text { Materials }\end{array}$} & \multirow{3}{*}{$\begin{array}{l}\text { Materials } \\
\text { Substitution \& } \\
\text { Composite } \\
\text { Materials }\end{array}$} & $\begin{array}{l}\text { Innovation, integrating lean and } \\
\text { sustainable manufacturing to } \\
\text { harmonise efficiency and } \\
\text { competitiveness }\end{array}$ & $\sqrt{ }$ & $\sqrt{ }$ & $\sqrt{ }$ & $\begin{array}{l}\text { Aguado et al. } \\
(2013)\end{array}$ \\
\hline & & $\begin{array}{l}\text { Environmental improvements related } \\
\text { to use of alternative materials }\end{array}$ & $\sqrt{ }$ & - & - & Alves et al. (2010) \\
\hline & & $\begin{array}{l}\text { Use of material innovation to } \\
\text { improve the sustainability of products } \\
\text { and processes with respect to people, } \\
\text { planet, and profit }\end{array}$ & $\sqrt{ }$ & $\sqrt{ }$ & $\sqrt{ }$ & $\begin{array}{l}\text { Crabbé, et al. } \\
\text { (2013) }\end{array}$ \\
\hline \multirow{4}{*}{$\begin{array}{l}\text { Organisation } \\
\text { (Society) }\end{array}$} & \multirow{4}{*}{ CSR } & $\begin{array}{l}\text { Procedure for measuring Corporate } \\
\text { Social Performance (CSP) }\end{array}$ & - & - & $\sqrt{ }$ & $\begin{array}{l}\text { Valiente et al., } \\
\text { (2012) }\end{array}$ \\
\hline & & $\begin{array}{l}\text { Guidelines for social life cycle } \\
\text { assessment of products }\end{array}$ & - & - & $\sqrt{ }$ & Benoît et al. (2010) \\
\hline & & Rigor for effective data collection & - & - & $\sqrt{ }$ & Grubert (2015) \\
\hline & & $\begin{array}{l}\text { Societal LCA methodology and its } \\
\text { connection with employment }\end{array}$ & $\sqrt{ }$ & - & $\sqrt{ }$ & Hunkeler (2006) \\
\hline
\end{tabular}

\subsection{Integrated Sustainability Performance Assessment - Towards Holistic LCSA}

The principles of ISO 14040 LCA have been applied in various articles and by many practitioners (Mastoris, 2011; Luong et al., 2012; Zamagni et al., 2013). However, in addition to its environmental centric approach, the complexity of the framework, the challenges and time required to collect an inventory of product's lifecycle make the framework impracticable (Consultants, 2000; Valdivia et al., 2013; Gbededo et al., 2016). Various researchers and practitioners in their proposition to achieve the goal of the LCSA have combined the principles of LCA with other methods for assessment and analysis of products sustainability (Hermann et al., 2007; Heijungs et al., 2010; Jacquemin et al., 2012; Parent et al., 2013; Valdivia et al., 2013). However, the challenges of capturing the social aspects in an integrated performance assessment approach have made many researchers to maintain the status-quo. Other researchers such as Kloepffer (2008) proposed an outline for LCSA that combines LCA, LCC, and S-LCA, but the author insisted that the system boundaries for the three dimensions' assessments have to be consistent and identical. Finkbeiner et al. (2010) presented the combination of LCSA, Life Cycle Sustainability Dashboard (LCSD) and Life Cycle Sustainability Triangle (LCST) as a communication and decision-making tool for stakeholders. Parent et al. (2013) reviewed the role and development of LCA and S-LCA in the context of Sustainable Production and Consumption pattern with Life Cycle Thinking (LCT) approach. These various approaches used the same methods of setting objectives and actions for product LCA to address LCC and S-LCA as in Finkbeiner et al. (2010). For instance, setting the goals of product LCA as a reduction of 
emission and uptake from the environment may follow by dematerialisation or substitution of materials with the focus on cost efficiency and creating values for consumers (Parent et al. 2013; Valdivia et al. 2013; Stefanova et al. 2014). In such instance, the S-LCA aspect would have a similar goal or objective to demand all supply chain actors comply with Corporate Social Responsibilities (CSR) ethos through improving the enterprise behaviour throughout the product lifecycle (Parent et al. 2013). According to this social approach, the authors emphasised that where the social behaviours of an actor is wrong and cannot be corrected, this could initiate the substitution of the supplier with focus on creating incentives for consumers, hence, the social emphasis is on knowing the behaviour of every actor within the supply chain or identifying the "hotspots" and possible options to reduce the potential impacts as in LCA. Parent et al. (2013) associate the economic part to creating price incentives and "eco-labels" for the consumers through technical optimisation of manufacturing process and distribution chain optimisation. Other research based on integrated assessment approaches are listed in Table 2. However, in agreement with other authors, these researchers believe that the holistic performance of products and in comparison to alternative products or previous versions have not been well assessed due to the complexity of the methods and the difficulties in integrating all the sustainability aspects of the assessment processes (Paju et al., 2010; Gbededo et al., 2016).

A holistic sustainability performance assessment incorporates the three sustainability dimensions in the assessment processes and aggregates the sustainability performance of all the actors in a product lifecycle to inform the product designers for effective decision-making (Consultants, 2000; Hutchins and Sutherland, 2008). According to Hutchins and Sutherland (2008), sustainability is appreciated when the interdependencies of the three sustainability dimensions are considered and analysed to support effective decision-making (Zamagni et al., 2013; Parent et al., 2013; Valdivia et al., 2013; Arena et al., 2013 and Sala et al., 2013). The authors further posited that it is necessary to characterise the connection and interactions among the three sustainability dimensions before we can achieve sustainable development.

Table 2. Summary of research based on integrated approach to sustainable manufacturing

\begin{tabular}{|c|c|c|c|c|c|c|c|}
\hline & : & 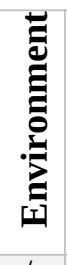 & 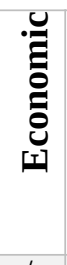 & . & & 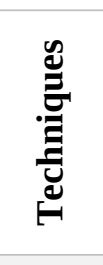 & 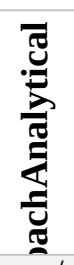 \\
\hline 1 & Kibira and McLean (2006) & $\sqrt{ }$ & $\sqrt{ }$ & $\sqrt{ }$ & Discrete Event Simulation (DES) & SPD & $\sqrt{ }$ \\
\hline 2 & Kloepffer (2008) & $\sqrt{ }$ & $\sqrt{ }$ & $\sqrt{ }$ & LCSA $=$ LCA + LCC + S-LCA & SPA & - \\
\hline 3 & Finkbeiner et al. (2010) & $\sqrt{ }$ & $\sqrt{ }$ & $\sqrt{ }$ & LCSA + LCSD + LCST & SPA & - \\
\hline 4 & Heijungs et al. (2010) & $\sqrt{ }$ & $\sqrt{ }$ & $\sqrt{ }$ & $\mathrm{LSCA}=\mathrm{LCA}+\mathrm{SA}$ & SPA & $\sqrt{ }$ \\
\hline 5 & Afgan (2010) & $\sqrt{ }$ & $\sqrt{ }$ & $\sqrt{ }$ & Energy Technology System & SPD & - \\
\hline 6 & Klöpffer and Ciroth (2011) & $\sqrt{ }$ & $\sqrt{ }$ & $\sqrt{ }$ & $\mathrm{LCSA}=\mathrm{LCA}+\mathrm{LCC}+\mathrm{S}-\mathrm{LCA}$ & SPA & - \\
\hline 7 & Swarr et al. (2011) & $\sqrt{ }$ & $\sqrt{ }$ & $\sqrt{ }$ & SETAC LCSA & SPA & - \\
\hline 8 & Schau et al. (2012) & $\sqrt{ }$ & $\sqrt{ }$ & $\sqrt{ }$ & $\mathrm{LCSA}=\mathrm{LCA}+\mathrm{LCC}+\mathrm{S}-\mathrm{LCA}$ & SPA & - \\
\hline 9 & Traverso et al. (2012) & $\sqrt{ }$ & $\sqrt{ }$ & $\sqrt{ }$ & L-C-S-DASHBOARD & SPA & - \\
\hline
\end{tabular}




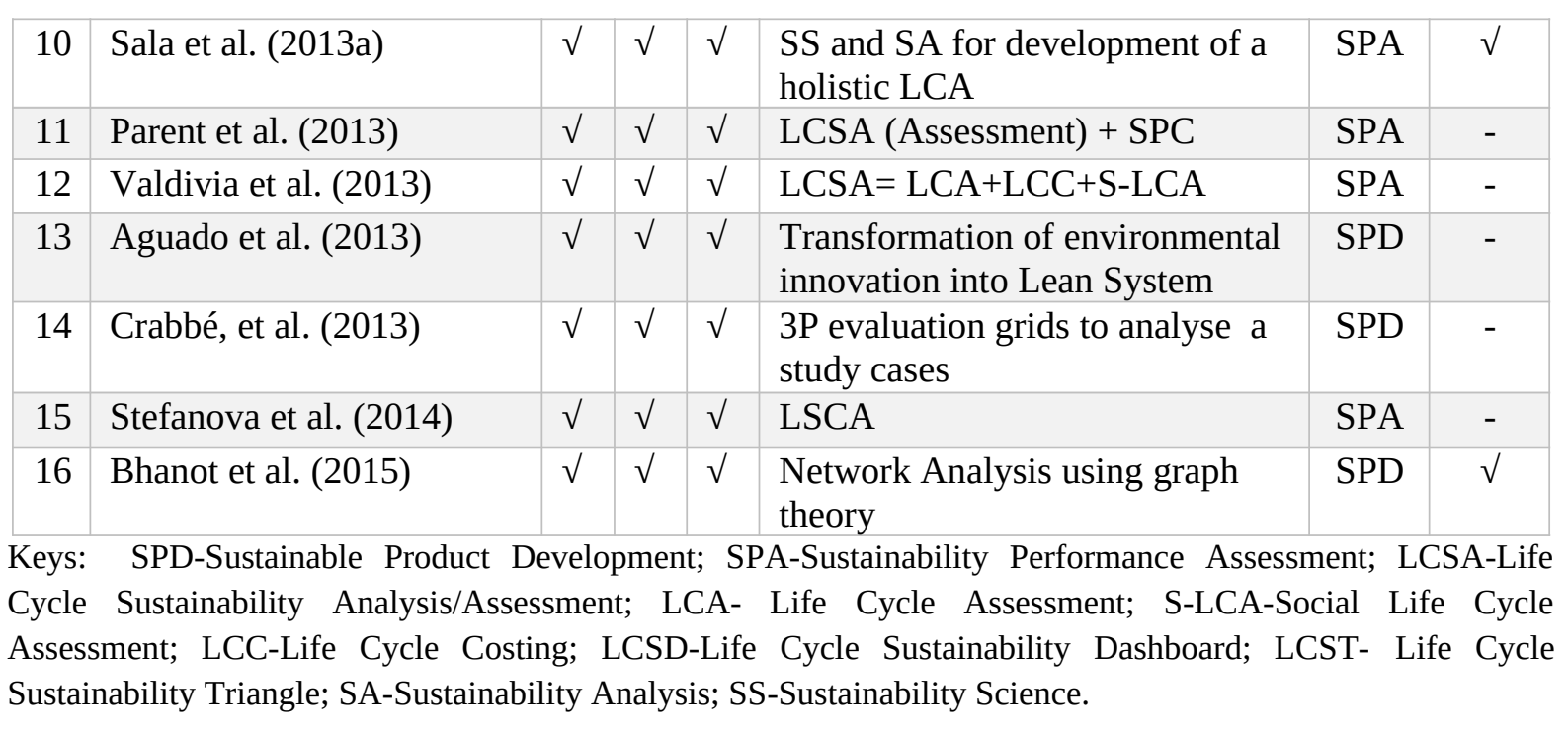

\subsection{Integrated Sustainable Product development: Challenges and Consolidated Approach}

In today's industries, sustainable product designers are charged with the responsibility to design products that are competitive, agile, social and environmentally friendly. According to Bonnie et al. (2014), in addition to functional and emotional criteria for the basis for which consumer choose among brands, a third dimension is now added based on the firm's social responsibility performance. Customers' demand patterns and product value perceptions have therefore changed. The legislative regulations are also placing greater demand on the manufacturing industry, but most especially on its production system and evaluation of associated energy consumption. Practically, there are many products in the market with "ecosignature” (ISO14001:1996) implying compliance to environmental or energy efficiency specification for the product use region (EUCOM, 2009). However, most of the eco-designed products are in sustainability sense, not sustainable without holistic assessment of the entire production system of the product including full consideration of the three sustainability dimensions (Parent et al., 2013; Valdivia et al., 2013). Most researchers have posited that strategic and life cycle thinking is currently the way forward for designing eco-efficient products (Halog and Manik, 2011; Parent et al., 2013; Zamagni et al., 2013). Thus, an integrated sustainable product is a product that is cost efficient, produced in an eco-efficient system, eco-efficient at the use phase, safe and socially acceptable. The result of this research indicates that 5 out of 36 articles that have adopted Sustainable Product Development (SPD) techniques considered the three sustainability dimensions in their approaches, see Figure 2 and Table 2.

\subsubsection{Consolidating Sustainability Assessment and Product Development Approach}

The importance of energy efficiency in manufacturing production processes is underscored in all the reviewed articles. The result shows that $100 \%$ of the approaches concentrate on the energy aspect. Methods such as energy modelling, eco-design, lean-green, and Energy Management Systems (Cannata et al., 2009; Melville and Ross, 2010; Leckner and Zmeureanu, 2011; Aramcharoen et al., 2014) are examples of strategies adopted in an ecoefficient production system that aims at reducing environmental impacts and cost of 
production (Rahimifard et al., 2010; Zamagni et al., 2013; Cataldo et al., 2013; Parent et al., 2013).

Circular Economy (CE) has also emerged to describe an approach that combines various design techniques under eco-design mechanisms with the aim of reducing the rate of consumption of natural resources through product lifespan extension and feasible economic case (Hu et al., 2011; Tukker, 2015; Esmaeilian et al., 2016). The main question, however, is; how sustainable are the production processes involved in manufacturing eco-innovative products? Or how do we assess their impacts on the economy, environment, and society in order to drive effective sustainability decisions?

Although there is a significant positive relationship between eco-innovative products and sustainable products (Brundtland, 1987; Luong et al., 2011; Aramcharoen and Mativenga, 2014), there is a need to align the manufacturing process of products with a holistic view of sustainable product development (Brundtland, 1987). This research, therefore, proposes an integrated methodology for impact analysis of production processes that enable the assessment of the three sustainability dimensions (i.e. economic, social and environmental) in a dynamic production environment.

\section{Analysis of the Existing Sustainable Manufacturing Approaches and Frameworks}

In this review, we presented existing approaches that support the development of sustainable products ranging from methods that deploy checklists and guidelines for eco-design products to those that use quantitative and analytical tools to assess the sustainability performance of a product lifecycle. Each of the approaches though, present a notable degree of weaknesses as discussed and highlighted in the previous sections and summarised in Table 3. According to Buchert et al. (2014), combining the advantages of the different existing sustainability approaches will facilitate continuous effective decision support. This section, therefore, presents the initial phase in the development of a holistic integrated framework that combines the advantages of existing approaches in order to support effective decision-making in sustainable product development. A detailed model and the validation process is presented in a subsequent article.

Table 3 Summary of techniques adopted in segmented approaches to sustainable manufacturing 


\begin{tabular}{|c|c|c|c|c|}
\hline Targets & $\begin{array}{c}\text { Sustainable Product } \\
\text { Development (SPD) } \\
\text { (Mechanisms) }\end{array}$ & $\begin{array}{c}\text { Sustainability Performance } \\
\text { Assessment (SPA) }\end{array}$ & Strengths & Weaknesses \\
\hline Product & $\begin{array}{ll}- & \text { Eco-design } \\
\text { - } & \text { Circular } \\
\text { Economy } \\
\text { Design for } \\
\text { Environment }\end{array}$ & $\begin{array}{ll}\text { - } & \text { Guidelines } \\
\text { - } & \text { Checklists } \\
\text { - } & \text { MET Matrix } \\
\text { - } & \text { Regulations \& } \\
& \text { Directives } \\
\text { - } & \text { LCA } \\
\text { - } & \text { LCC } \\
\text { - } & \text { S-LCA }\end{array}$ & 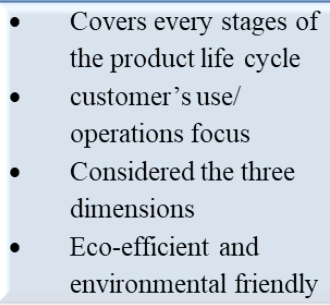 & $\begin{array}{l}\text { Partial / Sequential assessment } \\
\text { of the three dimensions } \\
\text { - Not focus on process } \\
\text { sustainability } \\
\text { Environment centric }\end{array}$ \\
\hline Process & $\begin{array}{ll}\text { - } & \text { Lean-green } \\
\text { - } & \text { Energy Modelling } \\
\text { - } & \text { Optimisation } \\
\text { - } & \text { Change } \\
\text { - } & \text { EMS } \\
\text { - } & \text { CSR }\end{array}$ & $\begin{array}{ll}\text { - } & \text { Throughput } \\
\text { - } & \text { Energy Efficiency } \\
\text { - } & \text { Resources Efficiency } \\
\text { - } & \text { CO2 Emission } \\
\text { - } & \text { Water \& other Wastes } \\
\text { - } & \text { Regulations \& } \\
\text { - } & \text { Directives } \\
\text { Employees' turnover }\end{array}$ & $\begin{array}{ll}\text { - } & \text { Covers the processing } \\
\text { - } & \text { stage } \\
\text { - } & \text { Elean Production } \\
\text { - } & \text { Green Process } \\
\text { - } & \text { Waste Reduction } \\
\text { - } & \text { Competitiveness } \\
\text { - } & \text { Employees' motivation }\end{array}$ & $\begin{array}{l}\text { - Does not consider the dynamic } \\
\text { production environment } \\
\text { - } \quad \text { Partial/ Sequential assessment } \\
\text { Lacks analysis of the } \\
\text { interdependency of the } 3 \\
\text { dimensions } \\
\text { Does not cover operations to } \\
\text { disposal stage }\end{array}$ \\
\hline
\end{tabular}

\subsection{An Optimal Sustainable Product}

A company's environmental impact is a function of the impacts of its production activities and processes, and the impacts of the main products produced by the company (Guziana, 2011). Thus, a single focus on designing or re-designing a product for environmental performance without considering the effects of the design on the production process may result in an ineffective decision for the design of a sustainable product. A product which design is optimised for environmental friendliness, but failed to consider the impact of the production process and other sustainability aspects of the manufacturing of the product is partially sustainable. Another partial approach exists when there are conflicts of priorities within the aspects of one of the sustainability dimensions. Nissen (1995) discussed a method for unifying "extreme-product-versions" into an "ideal-eco-product version" in a situation where eco-priorities are in conflict. The "extreme-product-versions" represent the uttermost/ best possible product versions of different aspects such as energy efficiency, materials efficiency or recyclability of an eco-product. Nissen (1995) emphasised the use of "ideal-ecoproduct approach" as an input for an eco-design process to achieve an "Ideal-eco-product versions", which is the unification or best compromise of "Extreme-product versions". However, this method neither addressed the unification of the product and process design criteria nor it considered the holistic approach to sustainable product design. Furthermore, sustainable manufacturing is a complex multi-criteria environment where the performance of one sustainability dimension is influenced by the other. Hence, a multi-objective optimisation that models decision-maker's preference based on the relative importance of sustainability objectives' functions and desired goals becomes paramount in attaining optimal sustainable product (Maker and Arora, 2004). This section, therefore, deploys multi-objective optimisation process with the view of using an analytical or simulation model to analyse and achieve the best set of compromise of the three sustainability dimensions.

\subsubsection{Partial-Sustainable-Product/Process}


In reference to the review and the summary presented in Table 3, In an eco-innovative environment; when the "target" for change is the product, various "mechanisms" are deployed based on the sustainability goal to design versions of eco-products while their environmental performances are assessed with eco-design tools such as checklists, guidelines, and LCA to achieve an "optimal-eco-product versions". Also, when the "target” for change is the production process, "mechanisms” such as lean-green and energy modelling are deployed with process performance assessment tools such as throughput and resource efficiency to achieve an "optimal-clean-process models”. Hence by inductive analysis, it can be stated that:

H1. The combination of SPD techniques and SPA tools in a product design may lead to an "optimal-eco-product version"

H2. The Combination of SPD techniques and SPA tools in a process design may lead to an "optimal-clean-process model”

However, a sustainable product, according to the findings of this research, is a product that is created using an eco-efficient manufacturing production process, conserves natural resources, is eco-efficient in the use phase, cost-efficient, safe and promotes social values and amenities for the workers and communities.

H3. Hence the combination of "H1" and "H2" above in a process that is economically efficient and promotes social values may lead to "partial-sustainable-product /process versions" see Figure 5.

A "partial-sustainable-product/process version" represents an optimal product/process in respect to a specific sustainability objective such as "optimal for environmental protection" or "optimal for economic development" or "optimal for social development". The trade-off or optimisation of the "partial-sustainable" versions to an attainable set and a feasible criterion space (Maker and Arora, 2004) for each of the dimensions is, therefore, paramount to an “optimal-sustainable-product/process” or “preferred sustainable product and process”.

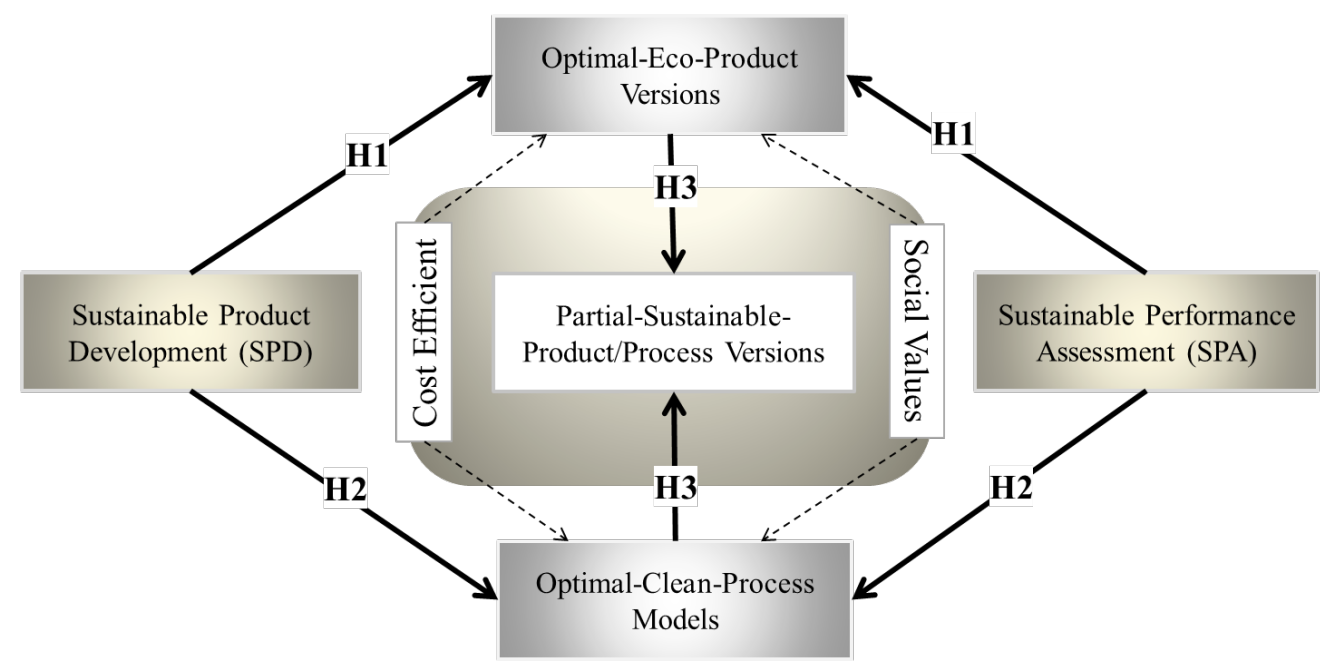

Figure 5 Partial-sustainable-product/process versions derived from SPD and SPA approaches 


\subsection{Optimisation of Sustainability Dimensions}

The successful outcome of the optimisation of the "partial-sustainable versions" of the three sustainability dimensions underpins the development of a holistic LCSA and determines the effectiveness of sustainability decision-making. The classical approach to unification of the "partial-sustainable versions" is demonstrated in the sequential integrated approaches as posited by many authors (Kloepffer, 2008; Afgan, 2000; Swarr et al., 2011; Schau et al., 2012). A sequential approach assesses the performance of each sustainability dimensions in the design process and sum-up the outcome. According to Valdivia et al. (2013), this approach does not take into consideration the interconnections and interdependencies of one dimension on the other hence, it is ineffective and does not support effective decision-making (Sala et al., 2013b). The authors posited that the outcome of each of the assessment should not be add-up but the interdependencies of the three dimensions must be analysed and evaluated for effective sustainability decision. The application of the principles of life cycle thinking, strategic thinking, and sustainability analysis thus becomes necessary to support the philosophy of LCSA (Valdivia et al., 2013; Sala et al., 2013b). This framework, therefore, proposed the "unification" or optimisation of the "partial-sustainable" versions in an analytical environment as depicted in Figure 6. Authors such as Bhanot et al. (2015) have used graph theory of network analysis to analyse the interdependencies of the three sustainability dimensions, some authors adopted mathematical modelling to analyse the three dimensions. Discrete-event simulation (DES) has been used by various authors to analyse and optimise environmental and economic aspects in a dynamic production environment and support trade-off scenario for effective manufacturing decisions (Kibira and Mclean, 2006). DES has the potential for process optimisation, energy modelling in a dynamic manufacturing production process and supports effective decision-making in a what-if scenario (Kibira and Mclean, 2006; Gbededo et al., 2016) hence, the adoption of a simulation-based "unification" or impact analysis of the "partial-sustainable-process models" to achieve a preferred/optimised sustainable product/process in a manufacturing production domain. 


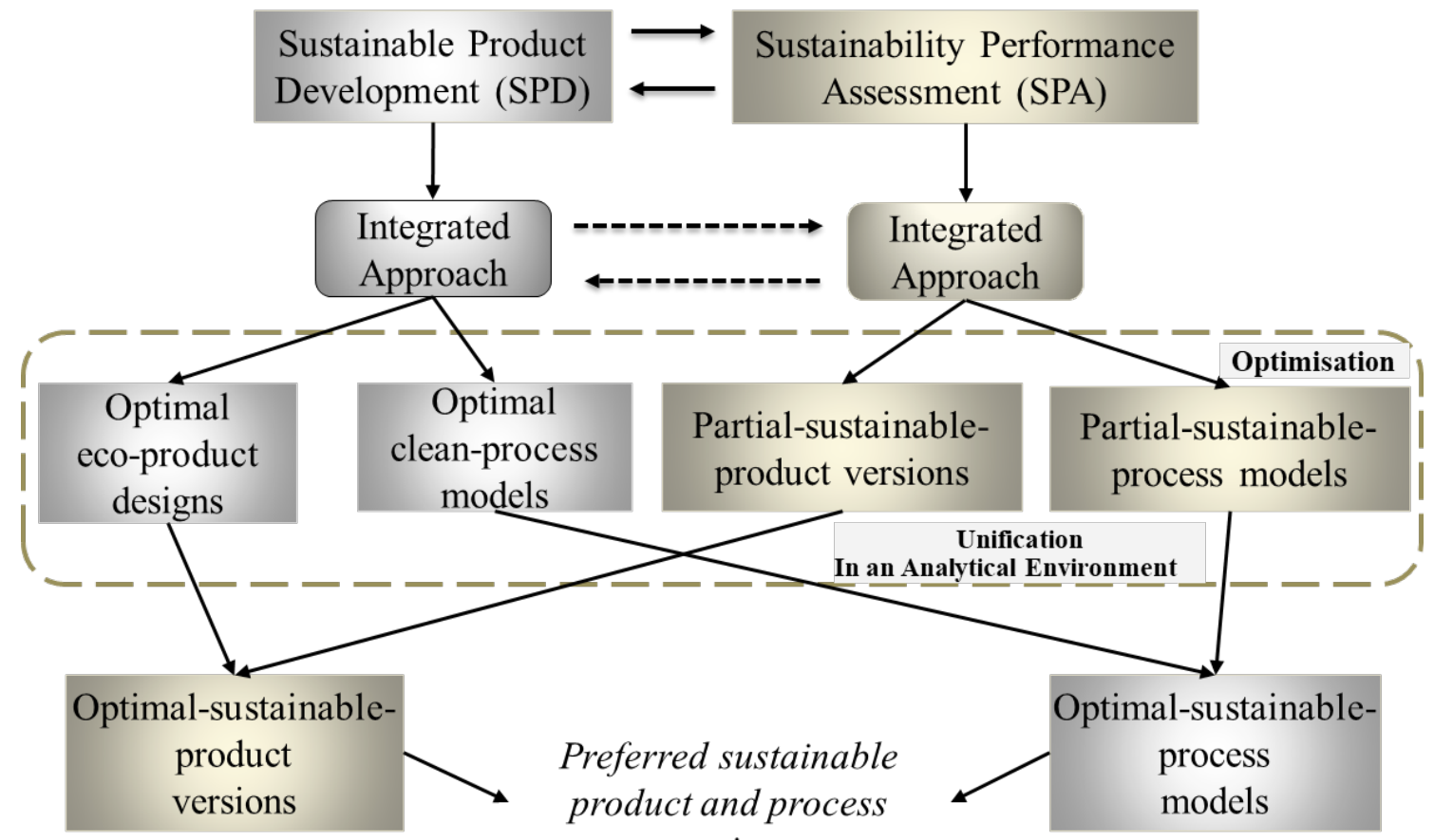
versions

Figure 6. Optimisation of partial-sustainable versions in an analytical environment

\subsection{The Holistic Simulation-based Sustainability Impact Analysis Framework}

The integration of DES with other sustainable manufacturing approaches into a common framework is not a new concept in sustainable product development (Kibira and McLean, 2006; Heilala, et al., 2008; Fakhimi et al., 2016). The combination of DES with SPD techniques and SPA tools has the potential to model production processes of a proposed or real scenario to investigate different production and sustainability aspects at different time intervals, reduce wastes, energy consumption, excessive time, and unused materials through process analysis and optimisation (Kibira and McLean, 2006; Widok, 2012). In addition, modern DES software such as SIMIO are armoured with functionalities that enable application of lean tools and techniques such as value stream mapping (VSM), just-in-time (JIT), bottleneck analysis, elimination of waste, continuous flow, and also a 3D animated graphic representation of the production process. Thus, so far, simulation provides the analytical environment for the impact analysis of environmental and economic aspects. Though some of the articles reviewed, discussed the importance of a holistic approach to sustainability, none presented a pragmatic approach that integrates the three sustainability dimensions in an analytical framework. Translating and converting qualitative social aspects into corresponding weighted values often eliminates social dimensions from the integrated sustainability analytical equations (Kibira and McLean, 2006; Paju et al., 2010).

The proposed integrated analytical framework represents a road-map to the development of an integrated conceptual modelling framework that would provide guidelines for sustainability practitioners to build a holistic simulation model that integrate the three 
sustainability aspects. A simplified theoretical framework of the simulation-based impact analysis is presented in Figure 7. The framework describes the process of integration of holistic sustainability functions into the "traditional" competitive product design process.

The first phase of the framework is the definition of the SPD goals and scope which highlights the aim, objectives, and boundaries for the proposed study. In the second phase, the problem statements are well crafted based on the sustainability missions and objectives to model the competitive manufacturing process, and design of the proposed sustainable product. In the "competitive manufacturing process design” axis, a strategic thinking is initiated based on the missions and objectives of the competitive strategies. The double-end arrows represents the iterative processes with continuous analysis with the SPA tools and checking with the combined competitive and sustainability "control elements" to generate new innovative ideas. The lower axis of "sustainable product design" deploys lifecycle thinking and sustainability strategies in an iterative process, with the SPA tools and continuous checking with the combined competitive and sustainability "control elements". The upper axis of the "competitive manufacturing process design" and the lower axis of "sustainable product design" generate "partial-sustainable-process models" and "partialsustainable-product versions" respectively. The parameters from the two axes which include process configuration, routing information, arrival rates, part-types, processing time, required resources, and CAD data are modelled into the input database. The model database provides an input for the DES software and, in an iterative process the DES experiments with the inputs, optimises and generates sustainable product and process options for evaluation. The response which includes sustainability and competitive performance indicators from the DES provides feedback for experimentation process and evaluation of resulting sustainability options. The process is repeated until a preferred option or sustainable solution is achieved based on the study objectives.

The proposed simulation-based sustainability impact analysis deploys the method of Productivity Factor (PF) and weighted Social Impact Coefficient (SIC) as the social inputs to the simulation parameters. The SIC which is determined in a predefined process as shown in the Figure 7 is an aggregated weighted value of the social impacts indices (positive and negative) of an organisation, and it corresponds to the labour factor productivity for socioeconomic development. Partial Factor Productivity (PFP) and Total Factor Productivity (TFP) are examples of PF used by practitioners to explain and improve efficiency and productivity of manufacturing inputs, economic growth, and improvement of income and welfare (The World Bank, 2000; Comin, 2008; Adak, 2009). The SIC represents an organisation social performance of defined stakeholder categories and can serve as a multiplier to sustainability analytical equation to determine the influence of social impacts on productivity. The social impact indices will also provide employers with insight into where there are high opportunities for improvement and high risks of threat. The successful calculation of SIC from the social indicators, therefore, enables integration of social aspects in a sustainability analytical equation, and the successful integration of the simulation-based sustainability impact analysis. 
This holistic approach will enable simulation modelling and sustainability impacts analysis of a partial-sustainable-product version under various sustainable production process controls and resources. The production process will be evaluated and optimised based on holistic sustainability objectives for the best competitive, sustainable process, and product design. 


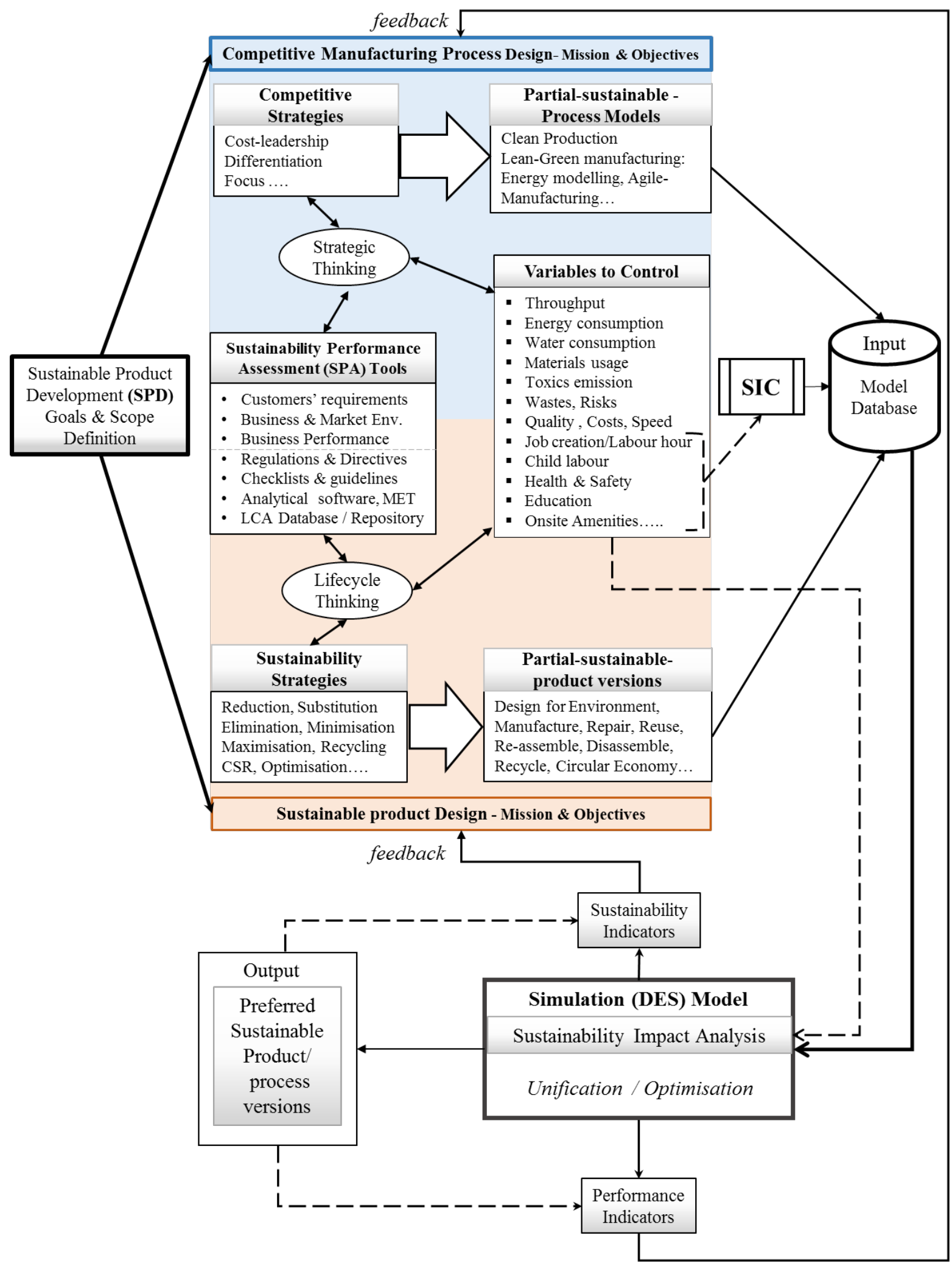

Figure 7. Theoretical framework for holistic simulation-based sustainability impact analysis 


\section{Summary and Conclusion}

In view of this literature review, the focus of the current research towards sustainable manufacturing is categorised into two major approaches; 1 ) the approaches that focus on the process, system or product's sustainability assessment in order to support decision-making, and 2) those that focus on innovative design or continuous improvement for sustainable process, system or product. The two categories are, however, faced with the challenge of integrating the three sustainability dimensions in their approaches hence, the segmented or integrated approach to each of the categories.

In this study, we have examined the different approaches to sustainable manufacturing, the trend towards the holistic LCSA and classified the focuses of the approaches. The result shows that most of the approaches lack of a holistic view and LCSA is still in an immature stage. Most of the authors focus on competitive manufacturing integrated with environmentally sustainable innovations, while other authors underscored the importance of holistic assessment of the three sustainability dimensions. As posited by many authors, sustainable development is achievable when the connection and interactions among the three sustainability dimensions are considered (Hutchins and Sutherland, 2008; Zamagni et al., 2013; Parent et al., 2013; Valdivia et al., 2013). It should be noted that the current approaches to sustainable manufacturing that integrates the three dimensions in their assessments do not consider the interdependencies of one dimension on the other. The approaches still use the traditional individual assessment methods and summing up their results. According to research, this approaches do not support effective decision-making and are prone to unintended negative consequences (Zamagni et al., 2013; Valdivia et al., 2013, Sala et al., 2013).

The proposed theoretical framework for simulation-based sustainability impact analysis will enable sustainability practitioners or eco-product designers to integrate goals that support progressive sustainable product development with methods that focus on the holistic quantitative analysis of the three sustainability dimensions (Zamagni et al., 2013; Sala et al., 2013). In the described concept, SPD and SPA approaches are deployed to establish partialsustainable-product versions and partial-sustainable-process-models of the three sustainability dimensions and optimise the partial-sustainable-process-models in a simulation-based analytical environment to achieve preferred sustainable product/process versions.

The application of the proposed framework is focused on the manufacturing production domain due to the limitation of the scope covered by this research. Hence there is still a clear gap for research on the issues of the influence of one sustainability dimension on the other across a product lifecycle, especially when assessing the sustainability of a process or product under design. Another obvious gap in the current research is the challenge of aggregating and translating various social aspects from qualitative to quantitative weighted values and the study of their influence on and interdependencies with the economic and environmental dimensions. Although UNEP (2009) has published guidelines for social LCA of products, the 
major challenge in S-LCA still remains classification and quantification of social criteria. According to Finkbeiner et al., (2010), there are over 150 proposals from various research fields for different social objectives and indicators. These indicators could be grouped under politics, society, women right, health, protection, and improvement of life, education, and CSR and then translated into a quantitative weighted value for assessment and to support decision-making. In a subsequent publication, we will discuss the process of calculating the productivity factor and weighted social impact coefficient (SIC) to enable an interdependent analysis of social aspects with the quantitative environmental and economic aspects. The method would also enable organisations to assess and improve their corporate social performances and productivity in respect of other sustainability dimensions.

\section{References}

Abidi, M., Lyonnet, B., Chevaillier, P. and Toscano, R. (2015) 'Contribution of Virtual Reality for Lines Production ’s Simulation in a Lean Manufacturing Environment', International Journal of Computer Theory and Engineering, 8(June), pp. 182-189. doi: 10.7763/IJCTE.2016.V8.1041.

Abramovici, M. and Lindner, A. (2011) 'Providing product use knowledge for the design of improved product generations’, CIRP Annals - Manufacturing Technology, 60(1), pp. 211-214. doi: 10.1016/j.cirp.2011.03.103.

Adak, M. (2009) 'Total Factor Productivity and Economic', İstanbul Ticaret Üniversitesi Sosyal Bilimler Dergisi Yıl:8 Sayı:15 Bahar 2009 pp. 49-56.

Afgan, N.H. (2010) "Sustainability Paradigm: Intelligent Energy System". Sustainability 2010, 2, 3812-3830; doi:10.3390/su2123812

Aguado, S., Alvarez, R., and Domingo, R. (2013) "Model of efficient and sustainable improvements in a lean production system through processes of environmental innovation". Journal of Cleaner Production 47 (2013) 141-148.

Almeida, C.M.V.B., Rodrigues, A.J.M., Bonilla, S.H., and Giannetti, B.F. (2010) Emergy as a tool for Ecodesign: evaluating materials selection for beverage packages in Brazil. Journal of Cleaner Production 18 (2010) 32-43.

Alves, C., Ferra, P. M. C., Silva, A. J., Reis, L. G., Freitas, M., Rodrigues, L. B. and Alves, D. E. (2010) 'Ecodesign of automotive components making use of natural jute fiber composites’, Journal of Cleaner Production, 18(4), pp. 313-327. doi: 10.1016/j.jclepro.2009.10.022.

Aramcharoen, A. and Mativenga, P. T. (2014) 'Critical factors in energy demand modelling for CNC milling and impact of toolpath strategy', Journal of Cleaner Production. Elsevier Ltd, 78, pp. 63-74. doi: 10.1016/j.jclepro.2014.04.065.

Arena, M., Azzone, G. and Conte, A. (2013) 'A streamlined LCA framework to support early decision making in vehicle development’, Journal of Cleaner Production. Elsevier Ltd, 41, pp. 105-113. doi: 10.1016/j.jclepro.2012.09.031.

Aydin, R., Kwong, C. K. and Ji, P. (2015) 'A novel methodology for simultaneous consideration of remanufactured and new products in product line design’, International Journal of Production Economics, 169, pp. 127-140. doi: 10.1016/j.ijpe.2015.07.022. 
Bakker, C., Wang, F., Huisman, J. and Den Hollander, M. (2014) 'Products that go round: Exploring product life extension through design', Journal of Cleaner Production. Elsevier Ltd, 69, pp. 10-16. doi: 10.1016/j.jclepro.2014.01.028.

Behrens, J,T, and Yu, C (2003) "Exploratory Data Analysis" Part One. Foundations of Research Issues: Study Design, Data Management, Data Reduction, and Data Synthesis, Published Online: 15 APR 2003 DOI: 10.1002/0471264385.wei0202

Bhanot, N., Rao, P. V. and Deshmukh, S. G. (2015) 'Sustainable Manufacturing: An Interaction Analysis for Machining Parameters using Graph Theory’, Procedia - Social and Behavioral Sciences. Elsevier B.V., 189, pp. 57-63. doi: 10.1016/j.sbspro.2015.03.192.

Bonnie J.K. Simpson Scott K. Radford , (2014),"Situational variables and sustainability in multi-attribute decisionmaking", European Journal of Marketing, Vol. 48 Iss 5/6 pp. 1046 - 1069.

Benoît, C., Norris, G. A., Valdivia, S., Ciroth, A., Moberg, A., Bos, U., Prakash, S., Ugaya, C. and Beck, T. (2010) 'The guidelines for social life cycle assessment of products: Just in time!', International Journal of Life Cycle Assessment, 15(2), pp. 156-163. doi: 10.1007/s11367-009-0147-8.

Brundtland, G. (1987)" Our Common Future: Report of the World Commission on Environment and Development" WCED, Journal of Medicine, Conflict and Survival, 1987, vol. 4, issue 1, Pg 300.

Buchert, T., Kaluza, A., Halstenberg, F. A., Lindow, K., Hayka, H. and Stark, R. (2014) 'Enabling product development engineers to select and combine methods for sustainable design’, Procedia CIRP. Elsevier B.V., 15, pp. 413-418. doi: 10.1016/j.procir.2014.06.025.

Cannata, A., Karnouskos, S., Taisch, M. (2009) "Energy efficiency driven process analysis and optimization in discrete manufacturing", 35th Annual Conference of IEEE on Industrial Electronics IECON '09, 3-5 November 2009

Cataldo, A., Taisch, M., Stah, B., 2013 "Modelling, simulation and evaluation of energy consumptions for a manufacturing production line. Industrial Electronics Society, IECON 2013 - 39th Annual Conference of the IEEE . Pg. 7537 - 7542.

Casamayor, J. L. and Su, D. (2013) 'Integration of eco-design tools into the development of eco-lighting products', Journal of Cleaner Production. Elsevier Ltd, 47, pp. 32-42. doi: 10.1016/j.jclepro.2013.02.011.

Chang, D., Lee, C. K. M. and Chen, C.-H. (2014) 'Review of Life Cycle Assessment towards Sustainable Product Development’, Journal of Cleaner Production. Elsevier Ltd, 83, pp. 48-60. doi: 10.1016/j.jclepro.2014.07.050.

Cluzel, F., Vallet, F., Tyl, B. and Leroy, Y. (2014). "Eco-design vs. eco-innovation: an industrial survey. 13th International Design Conference - DESIGN 2014, May 2014, Dubrovnik, Croatia. Proceedings of the 13th International Design Conference - DESIGN 2014, pp.1501- 1510, 2014. <hal-01144352>

Comin, D. (2008) ‘Total Factor Productivity’, The New Palgrave Dictionary of Economics, (August), pp. $1088-92$. doi: 10.1057/9781137336583.1849.

Consultants, P. (2000). "Eco-indicator 99 Manual for designers:A damage oriented method for Life Cycle Impact Assessment". Ministry of Housing, Spatial Planning and the Environment, The Hague, The Netherlands. http:// www.pre-sustainability.com/download/manuals/EI99 Manual.pdf

Crabbé, A., Jacobs, R., Hoof, V.V., Bergmans, A. and Acker, K.V. (2013) "Transition towards sustainable material innovation: evidence and evaluation of the Flemish case". Journal of Cleaner Production. Elsevier Ltd, 56, pp. 63-72. doi: 10.1016/j.jclepro.2012.01.023. 
Duflou, J. R., Seliger, G., Kara, S., Umeda, Y., Ometto, A. and Willems, B. (2008) 'Efficiency and feasibility of product disassembly: A case-based study', CIRP Annals - Manufacturing Technology, 57(2), pp. 583-600. doi: 10.1016/j.cirp.2008.09.009.

EUCOM, (2009) "Science for Environment Policy: DG Environment News Alert Services". European Commission DG ENV News Alert Issue 142 February 2009.

Fakhimi, M., Mustafee, N. and Stergioulas, L. K. (2016) 'An investigation into modelling and simulation approaches for sustainable operations management’, Simulation, 92(10), pp. 907-919. doi: 10.1177/0037549716662533.

Farmer, A.M. (2012) (Editor). Manual of European Environmental Policy. 1043pp. Routledge, London

Finkbeiner, M., Schau, E. M., Lehmann, A. and Traverso, M. (2010) 'Towards life cycle sustainability assessment', Sustainability, 2(10), pp. 3309-3322. doi: 10.3390/su2103309.

Gamage, J. R. and De Silva, A. K. M. (2015) 'Assessment of research needs for sustainability of unconventional machining processes’, Procedia CIRP. Elsevier B.V., 26, pp. 385-390. doi: 10.1016/j.procir.2014.07.096.

Gall, M. D., Gall, J. P., \& Borg, W. R. (2006) 'I dentifying a Research Problem and Question , and Searching’, Educational research: An introduction, pp. 21-42.

Garza-Reyes, J. A. (2015) 'Lean and green-a systematic review of the state of the art literature', Journal of Cleaner Production. Elsevier Ltd, 102, pp. 18-29. doi: 10.1016/j.jclepro.2015.04.064.

Gelbmann, U. and Hammerl, B. (2015) 'Integrative re-use systems as innovative business models for devising sustainable product-service-systems’, Journal of Cleaner Production. Elsevier Ltd, 97(2015), pp. 50-60. doi: 10.1016/j.jclepro.2014.01.104.

Gbededo, M.A., Liyanage, K. and Oraifige, I. (2016) "Simulation Aided Life Cycle Sustainability Assessment ( LCSA ) Framework for Manufacturing Design and Management” , Int. J. of Mechanical, Aerospace, Industrial, Mechatronic and Manufacturing Engineering, vol. 10, no. 7, pp. 1-3..

Gremyr, I., Siva, V., Raharjo, H. and Goh, T. N. (2014) 'Adapting the Robust Design Methodology to support sustainable product development', Journal of Cleaner Production. Elsevier Ltd, 79, pp. 231-238. doi: 10.1016/j.jclepro.2014.05.018.

Goodall, P., Rosamond, E. and Harding, J. (2014) 'A review of the state of the art in tools and techniques used to evaluate remanufacturing feasibility’, Journal of Cleaner Production. Elsevier Ltd, 81, pp. 1-15. doi: 10.1016/j.jclepro.2014.06.014.

Groover, M. P. 2010 "Fundamentals of Mordern Manufacturing: Materials, Processes and Systems" Edition, Fourth Published by John Wiley \& Sons Inc. ISBN 978-0470-467002

Grubert, E. (2016) 'Rigor in social life cycle assessment: improving the scientific grounding of SLCA', The International Journal of Life Cycle Assessment. The International Journal of Life Cycle Assessment. doi: 10.1007/s11367-016-1117-6.Guziana, B. (2011) "Is the Swedish environmental technology sector 'green'?". Journal of Cleaner Production 19 (2011) 827-835

Guziana, B. (2011) "Is the Swedish environmental technology sector 'green’?". Journal of Cleaner Production 19 (2011) 827-835

Haapala, K.R., Zhao, F., Camelio, J. Sutherland, J.W., Skerlos S.J., Dornfeld, D.A., Jawahir, I.S., Zhang, H.C., and Clarens, A.F., (2011)"A Review of Engineering Research in Sustainable Manufacturing" Proceedings of the ASME 2011 International Manufacturing Science and Engineering Conference MSEC2011 June 13-17, 2011, Corvallis, Oregon, USA 
Halog A. and Manik Y. (2011) Advancing Integrated Systems Modelling Framework for Life Cycle Sustainability Assessment. Open Access Sustainability 2011, 3, 469-499; doi:10.3390/su3020469. www.mdpi.com/journal/sustainability

Hatcher, G. D., Ijomah, W. L. and Windmill, J. F. C. (2011) 'Design for remanufacture: A literature review and future research needs', Journal of Cleaner Production. Elsevier Ltd, 19(17-18), pp. 2004-2014. doi: 10.1016/j.jclepro.2011.06.019.

Heijungs, R., Huppes, G. and Guinée, J. (2009) 'A scientific framework for LCA', Deliverable D15 of the CALCAS project (http://www. calcasproject. net or http://www. estis. net/sites/calcas/), 18(4), pp. 375-385. doi: 10.1016/j.jclepro.2009.10.020.

Heilala, J., Vatanen, S., Tonteri, H., Montonen, J., Lind, S. and Johansson, B. Stahre, J. (2008) 'Simulation-Based Sustainable Manufacturing System Design’, 2008 Winter Simulation Conference, pp. 1922-1930. doi: 10.1109/ WSC.2008.4736284.

Hermann, B. G., C. Kroeze and W. Jawjit. 2007. Assessing environmental performance by combining life cycle assessment, multi-criteria analysis and environmental performance indicators. J. Clean. Prod. 15(18): 17871796.

Hong, J., Zhou, J., Hong, J. and Xu, X. (2012) 'Environmental and economic life cycle assessment of aluminumsilicon alloys production: a case study in China', Journal of Cleaner Production, 24, pp. 11-19. doi: 10.1016/j.jclepro.2011.11.003.

Hu, J., Xiao, Z., Zhou, R., Deng, W., Wang, M. and Ma, S. (2011) 'Ecological utilization of leather tannery waste with circular economy model', Journal of Cleaner Production. Elsevier Ltd, 19(2-3), pp. 221-228. doi: 10.1016/j.jclepro.2010.09.018.

Hunkeler, D. (2006) 'Societal LCA Methodology and Case Study', The International Journal of Life Cycle Assessment, 11(6), pp. 371-382. doi: 10.1065/lca2006.08.261.

Hunkeler, D., Lichtenvort, K. and Rebitzer, G. (2008) "Environmental Life Cycle Costing". 2008 by the Society of Environmental Toxicology and Chemistry (SETAC). Downloaded by [31.205.58.5] at 16:09 04 September 2016.

Hutchins, M.J. and Sutherland, J.W. (2008) "An exploration of measures of social sustainability and their application to supply chain decisions". Journal of Cleaner Production 16 (2008) 1688-1698.

Ijomah, W. L., McMahon, C. A., Hammond, G. P. and Newman, S. T. (2007) 'Development of design for remanufacturing guidelines to support sustainable manufacturing', Robotics and Computer-Integrated Manufacturing, 23(6), pp. 712-719. doi: 10.1016/j.rcim.2007.02.017.

ISO 14000 family of International Standards -Environmental management - (no date). Available at: https://www.iso.org/publication/PUB100238.html (Accessed: 24 February 2018).

ISO 14040:2006 - Environmental management -- Life cycle assessment -- Principles and framework (no date). Available at: https://www.iso.org/standard/37456.html (Accessed: 24 February 2018).

ISO 14044:2006 - Environmental management -- Life cycle assessment -- Requirements and guidelines (no date). Available at: https://www.iso.org/standard/38498.html (Accessed: 24 February 2018).

Jacquemin L., Pontalier P.Y., and Sablayrolles C. (2012) Life cycle assessment (LCA) applied to the process industry: a review. International Journal of Life Cycle Assessment, Springer Verlag, 2012, vol. 17, pp. 1028-1041. $<10.1007 /$ s11367-012-0432-9>. <hal-00741389> 
Jovane, F., Yoshikawa, H., Alting, L., Boër, C. R., Westkamper, E., Williams, D., Tseng, M., Seliger, G. and Paci, A. M. (2008) 'The incoming global technological and industrial revolution towards competitive sustainable manufacturing', CIRP Annals - Manufacturing Technology, 57(2), pp. 641-659. doi: 10.1016/j.cirp.2008.09.010.

Kalakul, S., Malakul, P., Siemanond, K. and Gani, R. (2014) 'Integration of life cycle assessment software with tools for economic and sustainability analyses and process simulation for sustainable process design’, Journal of Cleaner Production, 71, pp. 98-109. doi: 10.1016/j.jclepro.2014.01.022.

Kara, S. and Li, W. (2011) 'Unit process energy consumption models for material removal processes’, CIRP Annals Manufacturing Technology, 60(1), pp. 37-40. doi: 10.1016/j.cirp.2011.03.018.

Keskin, D., Diehl, J. C. and Molenaar, N. (2013) 'Innovation process of new ventures driven by sustainability', Journal of Cleaner Production. Elsevier Ltd, 45, pp. 50-60. doi: 10.1016/j.jclepro.2012.05.012.

Kibira D. and McLean C., (2008) "Modeling and Simulation for Sustainable Manufacturing". Science and Technology Innovation for Sustainable Development. Proceedings of the 2nd IASTED 2008 Africa Conference on Modeling and Simulation. Pg 11 pp.

Kloepffer, W. (2008) 'Life Cycle Sustainability Assessment of Products (with Comments by Helias A. Udo de Haes, p. 95)’, International Journal Life Cycle Assessment, 13(2), pp. 89-95. doi: http://dx.doi.org/10.1065/lca2008.02.376.

Klöpffer, W. and Ciroth, A. (2011) 'Is LCC relevant in a sustainability assessment?', International Journal of Life Cycle Assessment, 16(2), pp. 99-101. doi: 10.1007/s11367-011-0249-y.

Krozer, J. and Vis, J. C. (1998) 'How to get LCA in the right direction?’, Journal of Cleaner Production, 6(1), pp. 5361. doi: 10.1016/S0959-6526(97)00051-6.

Kubota, F. I. and Da Rosa, L. C. (2013) 'Identification and conception of cleaner production opportunities with the Theory of Inventive Problem Solving', Journal of Cleaner Production. Elsevier Ltd, 47, pp. 199-210. doi: 10.1016/j.jclepro.2012.07.059.

Leckner, M. and Zmeureanu, R. (2011) 'Life cycle cost and energy analysis of a Net Zero Energy House with solar combisystem’, Applied Energy. Elsevier Ltd, 88(1), pp. 232-241. doi: 10.1016/j.apenergy.2010.07.031.

Lim, S., Kim, Y.R., Woo, S.H., Park , D., and Park, J.M. (2013) "System optimization for eco-design by using monetization of environmental impacts: a strategy to convert bi-objective to single-objective problems". Journal of Cleaner Production 39 (2013) 303-311.

Luong S, Liu K. and Robey J. (2012) "Sustainability Assessment Framework for Renewable Energy Technology".www.reading.ac.uk/web/FILES/tsbe/Luong_TSBE_Conference_Paper_2012.pdf. Accessed Oct 12, 2016

Luz, S. M., Caldeira-Pires, A. and Ferr??o, P. M. C. (2010) 'Environmental benefits of substituting talc by sugarcane bagasse fibers as reinforcement in polypropylene composites: Ecodesign and LCA as strategy for automotive components', Resources, Conservation and Recycling. Elsevier B.V., 54(12), pp. 1135-1144. doi: 10.1016/j.resconrec.2010.03.009.

Marler, R.T. and Arora, J.S. (2004) “Survey of multi-objective optimization methods for engineering”. Struct Multidisc Optim 26, 369-395 (2004). DOI 10.1007/s00158-003-0368-6. Available on https://link.springer.com/article/10.1007/s00158-003-0368-6

Mastoris, I. (2011) “Towards a framework of products life cycle sustainability assessment (LCSA)”. The ESPRC Centre for Innovative Manufacturing in Industrial Sustainability Institute for Manufacturing, University of Cambridge 2011 
Melville, N.P. and Ross, S.M. (2010) "Information Systems Innovation For Environmental Sustainability" Melville/IS Innovation for Environmental Sustainability. MIS Quarterly Vol. 34 No 1, pp. 1-21/march 2010

Mitchell, L. and Radu, Z. (2011) "Life cycle cost and energy analysis of a net zero energy house with solar combisystem”. Applied Energy. Volume 88, Issue 1, January 2011, Pages 232-241

Mori, M., Fujishima, M., Inamasu, Y. and Oda, Y. (2011) 'A study on energy efficiency improvement for machine tools’, CIRP Annals - Manufacturing Technology, 60(1), pp. 145-148. doi: 10.1016/j.cirp.2011.03.099.

Nissen, U. (1995) 'A methodology for the development of cleaner products. The ideal-eco-product approach', Journal of Cleaner Production, 3(1-2), pp. 83-87. doi: 10.1016/0959-6526(95)98166-L.

OECD Multilingual Summaries, (2010) "Eco-Innovation in Industry: Enabling Green Growth" Execustive Summary of OECD Project on Sustainable Manufacturing and Eco-innovation. ISBN 978-92-64-077218 (C) OECD 2010 - 1

Ostlin, J., Sundin, E. and Bjorkman, M. (2009) "Product life-cycle implications for remanufacturing strategies". Journal of Cleaner Production 17 (11), pp 999-1009. doi: 10.1016/j.jdepro.2009.02.021

Page, B. and Wohlgemuth, V., (2010) "Advances in environmental informatics: integration of discrete event simulation methodology with ecological material flow analysis for modelling eco-efficient systems". Procedia Environmental Sciences International Conference on Ecological Informatics and Ecosystem Conservation (ISEIS 2010),2, 696-705

Paju, M., Heilala, J., Hentula, M., Heikkila, A., Johansson, B., Leong, S., and Lyons, K. 2010. "Framework and Indicators for a Sustainable Manufacturing Mapping Methodology". Proceedings of the 2010 Winter Simulation Conference

Parent J, Cucuzzella C, Revéret JP (2013) Revisiting the role of LCA and SLCA in the transition towards sustainable production and consumption.Int J Life Cycle Assess (2013) 18:1642-1652 doi:10.1007/s11367-012-0485-9.

Portha, J.-F., Jaubert, J.-N., Louret, S. and Pons, M.-N. (2010) 'Life Cycle Assessment Applied to Naphtha Catalytic Reforming’, Oil \& Gas Science and Technology - Revue d’IFP Energies nouvelles, 65(5), pp. 793-805. doi: 10.2516/ogst/2010019.

Pryshlakivsky, J. and Searcy, C. (2013) 'Fifteen years of ISO 14040: A review', Journal of Cleaner Production. Elsevier Ltd, 57, pp. 115-123. doi: 10.1016/j.jclepro.2013.05.038.

Rahimifard, S., Seow, Y., Childs, T. (2010) "Minimising Embodied Product Energy to support energy efficient manufacturing" CIRP Annals - $\quad$ Manufacturing $\quad$ Technology $59 \quad$ (2010) 25-28. www.ees.elsevier.com/cirp/default.asp

Rajemi, M. F., Mativenga, P. T. and Aramcharoen, A. (2010) 'Sustainable machining: Selection of optimum turning conditions based on minimum energy considerations’, Journal of Cleaner Production. Elsevier Ltd, 18(10-11), pp. 1059-1065. doi: 10.1016/j.jclepro.2010.01.025.

Rai, S. and Daniels, M. (2015) "An Event-Log Analysis and Simulation-Base Approach for Quantifying Sustainability Metrics in Production Facilities". Proceedings of the 2015 Winter Simulation Conference. pp 1033-1043

Rehfeld, K.M, Rennings, K and Ziegler, A. (2007) "Integrated product policy and environmental product innovations: An empirical analysis". E C OL OG I C AL ECONOM I C S 61 ( 20 07) 91 - 100 available at www.sciencedirect.com.

Ribeiro, F. D. M. and Kruglianskas, I. (2013) 'Improving environmental permitting through performance-based regulation: A case study of Sao Paulo State, Brazil’, Journal of Cleaner Production. Elsevier Ltd, 46, pp. 15-26. doi: 10.1016/j.jclepro.2012.09.017. 
Rosen, M. A. and Kishawy, H. A. (2012) "Sustainable Manufacturing and Design: Concepts, Practices and Needs". Sustainability-Open Access Journal 2012, 4(2), 154-174; doi:10.3390/su4020154. http://www.mdpi.com/2071$\underline{1050 / 4 / 2 / 154 / \mathrm{htm}}$

Sala, S., Farioli, F. and Zamagni, A. (2013) 'Life cycle sustainability assessment in the context of sustainability science progress (part 2)’, International Journal of Life Cycle Assessment, 18(9), pp. 1686-1697. doi: 10.1007/s11367012-0509-5.

Sala, S., Farioli, F. and Zamagni, A. (2013b) 'Progress in sustainability science: Lessons learnt from current methodologies for sustainability assessment: Part 1', International Journal of Life Cycle Assessment, 18(9), pp. 1653-1672. doi: 10.1007/s11367-012-0508-6.

Schau, E.M., Traverso, M. and Finkbeiner, M. (2012) "Life cycle approach to sustainability assessment: a case study of remanufactured alternators". Journal of Remanufacturing, pp. 1-14. doi: 10.1186/2210-4690-2-5. http://www.journalofremanufacturing.com/content/2/1/5

Seow, Y., Rahimifard, S. and Woolley, E. (2013) 'Simulation of energy consumption in the manufacture of a product', International Journal of Computer Integrated Manufacturing, 26(7), pp. 663-680. doi: 10.1080/0951192X.2012.749533.

Singh, R.K., Murty, H.R, Gupta, S.K. and Dikshit, A.K. (2012) "An overview of sustainability assessment methodologies". Ecological Indicators 15 (2012) 281-299.

Solding, P., Petku, D., and Mardan, N. (2009) "Using simulation for more sustainable production systems methodologies and case studies". International Journal of Sustainable Engineering, Vol. 2, No. 2, June 2009, 111-12

Stefanova, M., Tripepi, C., Zamagni, A. and Masoni, P. (2014) 'Goal and Scope in Life Cycle Sustainability Analysis: The Case of Hydrogen Production from Biomass’, Sustainability, 6(8), pp. 5463-5475. doi: 10.3390/su6085463

Stevens, C. (2005) "Measuring Sustainable Development" Statistics Brief - Organisation for Economic Co-operation and Development (OECD). September 2005 No. 10

Swarr, T. E., Hunkeler, D., Kl??pffer, W., Pesonen, H. L., Ciroth, A., Brent, A. C. and Pagan, R. (2011) 'Environmental life-cycle costing: A code of practice', International Journal of Life Cycle Assessment, 16(5), pp. 389-391. doi: 10.1007/s11367-011-0287-5.

The World Bank (2000) 'Measuring Growth in Total Factor Productivity', Economic Policy. doi: 10.1179/136485908X337463.

Thiede, S., Seowb, Y., Andersson, J. and Johansson, B. (2013) "Environmental aspects in manufacturing system modelling and simulation-State of the art and research perspectives". CIRP Journal of Manufacturing Science and Technology 6 (2013) 78-87.

Tranfield, D., Denyer, D. and Smart, P. (2003) 'Towards a methodology for developing evidence-informed management knowledge by means of systematic review *', British Journal of Management, 14, pp. $207-222$. doi: 10.1111/1467-8551.00375.

Traverso, M., Asdrubali, F., Francia, A. and Finkbeiner, M. (2012) 'Towards life cycle sustainability assessment: An implementation to photovoltaic modules', International Journal of Life Cycle Assessment, 17(8), pp. 10681079. doi: 10.1007/s11367-012-0433-8.

Tukker, A. (2015) 'Product services for a resource-efficient and circular economy - A review', Journal of Cleaner Production. Elsevier Ltd, 97, pp. 76-91. doi: 10.1016/j.jclepro.2013.11.049. 
U.S. Life Cycle Inventory Database." (2012). National Renewable Energy Laboratory, 2012. Accessed November 19, 2012: https://www.lcacommons.gov/nrel/search

UNEP, 1998. Cleaner Production and Eco-efficiency: from Ideas to Action. UNEP, Geneve.Van

UNEP/SETAC, (2009). "Life cycle initiative (2009) guidelines for social life cycle assessment of products”. ISBN: 978-92-807-3021-0. DTI/1164/PA

Valdivia S, Ugaya C.M.L., Hildenbrand j., Traverso M., Mazijn B. and Sonnemann G. (2013) A UNEP/SETAC approach towards a life cycle sustainability assessment-our contribution to Rio+20:Life Cycle Sustainability Assessment: From LCA to LCSA. Int J Life Cycle Assess (2013) 18:1673-1685 DOI 10.1007/s11367-0120529-1.

Yang, M. G., Hong, P. and Modi, S. B. (2011) 'Impact of lean manufacturing and environmental management on business performance: An empirical study of manufacturing firms', International Journal of Production Economics. Elsevier, 129(2), pp. 251-261. doi: 10.1016/j.ijpe.2010.10.017.

Zamagni, A., Pesonen, H.-L. and Swarr, T. (2013) 'From LCA to Life Cycle Sustainability Assessment: concept, practice and future directions', The International Journal of Life Cycle Assessment, 18(9), pp. 1637-1641. doi: 10.1007/s11367-013-0648-3.

Zeng, S. X., Meng, X. H., Yin, H. T., Tam, C. M. and Sun, L. (2010) 'Impact of cleaner production on business performance', Journal of Cleaner Production. Elsevier Ltd, 18(10-11), pp. 975-983. doi: 10.1016/j.jclepro.2010.02.019. 